\title{
18 MART MUTABAKATI: BİR HUKUKİ ANALIZZ
}

\section{Burak ERDENIR* \\ Araştırma Makalesi}

$\ddot{\boldsymbol{O}_{z}}$

2015 yılında ortaya çıkan gö̧̧men krizini hafifletebilmek amacıyla Türkiye ile AB arasinda yapılan 18 Mart Mutabakatl, caydırıcı etkisiyle Ege'de ölümleri büyük ölçüde önlemeyi başarmıştır. Ancak, mutabakatın temel unsuru olan "I'e 1" uygulamasının uluslararası hukuka ve AB hukukuna aykırı olduğu farklı çevrelerce iddia edilmişti. $A B$ kurumları da mutabakatın $A B A D$ 'ın yargı denetimine takılmasını engellemek için mutabakatla bağlantıları olmadığını ileri sürmüşlerdir. Siyaseten mantıklı bir tercih olarak görünmekle beraber, AB açısından hukuken sorunlu bir durum ortaya çıkmıştır. Makale, 18 Mart Mutabakatın hukuki bir perspektiften ele almakta olup, AB'nin hangi kurum tarafindan temsil edildiği ve Mutabakatın uluslararası anlaşma niteliği taşıyıp taşımadığı hususlarını irdelemektedir. 18 Mart Mutabakatı ve akdedildiği bağlam hukuken irdelendiğinde, bu metnin AB adına hareket eden AB Zirvesi ile Türkiye arasında yapılan bir politik mutabakat olduğu sonucuna varlmaktadır.

Anahtar Kelimeler: 18 Mart Mutabakatl, AB-Türkiye Bildirisi, Geri Kabul Anlaşması, Göçmen Krizi, Avrupa Birliği Adalet Divanı

\section{EU-Turkey Migration Deal: A Legal Analysis}

\section{Abstract}

EU-Turkey Migration Deal of 2015, succeeded to curb deaths in the Aegean thanks to its deterring impact. However, it was criticized on the grounds that the " 1 for 1" formula was against international and EU law. EU institutions claimed they had not taken part in the deal to avoid the annulment of the deal by EU's Court of

* Doç. Dr., Avrupa Birliği Başkanlığı, E-Posta: berdenir@ab.gov.tr, ORCID: 0000-00020862-5684.

Makalede yer alan görüşler yazara ait olup, Avrupa Birliği Başkanlığını herhangi bir şekilde bağlamaz.

Makalenin Gönderilme Tarihi: 08/07/2021 Kabul Edilme Tarihi: 13/10/2021 
Justice. This article analyzes the deal from a legal perspective to figure out which actor had been a part of the deal on behalf of the EU and whether the deal qualifies as an international agreement. The legal analysis indicates that the Statement appears to be a political arrangement rather than an international agreement concluded between Turkey and the European Council representing the EU.

Keywords: 18 March Statement, EU-Turkey Migration Deal, Readmission Agreement, Refugee Crisis, European Court of Justice

\section{Giriş}

2015 yılında ortaya çıkan göçmen krizi sonrasında Türkiye ile Avrupa Birliği (AB) arasında yapılan 18 Mart Mutabakatı siyasi, hukuki ve hatta ahlaki bakımdan birçok tartışmanın odağı olmuştur. Özellikle insani bir trajedinin önüne geçilmesine yönelik bir çaba olması nedeniyle belli çevreler mutabakata övgüyle yaklaşırken, eleştiriler ise taraf ülkelerin çıkarları için insan hakları ve mülteci haklarının ihlal edilmesine göz yumdukları şeklindeydi. Uluslararası Af Örgütü, mültecilerin trajik durumunu görmezden geldiğini iddia ettiği AB'yi suçlayarak Mutabakatı "Avrupa'nın Utanç Y1lı" olarak nitelendirmişti. ${ }^{1}$

Mutabakatı eleştiren çevreler, Mutabakatta öngörülen "1'e 1" formülüyle AB'nin göçmenleri Türkiye'ye hukuksuz bir şekilde geri göndereceği iddiasıyla, Mutabakatın $\mathrm{AB}$ hukuku ve uluslararası hukuka aykırı olduğunu ileri sürmüşlerdir. Oysa, $A B$ ve Türkiye'nin amacı Ege'de göçmen ölümlerinin önlenmesi ve insan kaçakçıllğ zincirinin kırılması idi. Nitekim, Mutabakat ilk yılında etkisini hemen göstermiş, AB Komisyonu verilerine göre düzensiz geçişler \% 97 oranında azalmıştı. En fazla eleştiriye maruz kalan "1'e 1"uygulaması kapsamındaki iadeler ve AB ülkelerine yerleştirmeler sınırlı sayıda kalmış ama 18 Mart Mutabakatı caydırıcı etkisiyle Ege Denizi üzerinden düzensiz göçleri ve dolayısıyla can kaybını önemli ölçüde engellemişti.

AB kurumları da hedefe ulaşma yolunda Mutabakata getirilen suçlamaları bertaraf etmek için ilginç bir yöntem belirlemişti; fiilen Mutabakata sahip çıkıp uygulanmasını sağlarken, hukuken sorumluluktan sıyrılmaya çalışmışlardır. Zira, AB kurumları Mutabakatın tarafı olarak kabul edilse idi, Mutabakat Avrupa Birliği Adalet Divanı'nın(ABAD) yargı

1 https://www.amnesty.org/en/latest/news/2017/03/the-eu-turkey-deal-europes-year-of-shame/ Erişim Tarihi: Haziran 2021. 
denetimine takılacaktı. Nitekim, ABAD'1n önüne gelen davada, AB kurumları Yüksek Mahkemeye gönderdikleri savunmalarında Mutabakatın tarafı olmadıklarını iddia etmişler, ABAD da $\mathrm{AB}$ kurumlarının argümanlarını temel alarak, metnin $\mathrm{AB}$ Zirvesi tarafindan değil üyesi ülke Devlet ve Hükümet Başkanları tarafindan akdedildiği sonucuna vararak, yarg1 denetimi görevini ifa etmemeyi tercih etmiştir. Yüksek bir amaç uğruna $\mathrm{AB}$ kurumlarının böyle bir pozisyon aldığı iddia edilse de, hukuken oldukça sorunlu bir durum ortaya çıkmıştır.

AB kurumlarının Mutabakatla bağlantısı olmadığı sonucuna varan ABAD'ın 18 Mart Mutabakatına ilişkin kararı, muhtemelen hukuki ve teknik bir gelişme olarak belirdiğinden Türkiye'de fazla ses getirmemiştir. Nitekim, Türk kamuoyunun ve Türk yetkililerinin Mutabakatın AB ile yapıldığına dair bir şüphesi bulunmamaktadır. Oysa, AB kurumlarının aldığ 1 bu pozisyon, Türkiye ile $\mathrm{AB}$ arasında özellikle son dönemde artan güven bunalımını derinleştirecek niteliktedir.

Makale, 18 Mart Mutabakatının Türkiye'de pek tartışılmayan hukuki boyutunu irdelemektedir. Mutabakatın hukuki niteliğine yönelik tartı̧̧ma, temelde iki boyutta olmaktadır. Bir taraftan, metnin hukuken bağlayıcı nitelikte uluslararası bir anlaşma $\mathrm{m}$ 1 yoksa politik/idari bir düzenleme mi olduğu konusu tartışılmaktadır. İkinci boyut olarak ise, AB tarafını temsilen üye ülke temsilcilerinin Türkiye ile toplantıya $\mathrm{AB}$ Zirvesi üyeleri olarak $\mathrm{m}$ yoksa Devlet ve Hükümet Başkanları sıfatlarıyla katıldıkları ve karar aldıkları sorusu tartışılmaktadır.

Makalede, öncelikle 18 Mart Mutabakatı içeriği ve uygulaması değerlendirilmekte, daha sonra ABAD'ın Mutabakata ilişkin kararı ele alınmaktadır. 18 Mart Mutabakatının hukuki niteliğini ortaya çıkarmak üzere, öncelikli olarak AB'nin kim tarafından temsil edildiği sorusu yanıtlanmaya çalış1lıp, ikinci soru olan Mutabakatın uluslararası anlaşma olup olmadığ 1 hususu irdelenmektedir. Son olarak, 18 Mart Mutabakatına ilişkin $\mathrm{AB}$ kurumlarının aldığı pozisyon üzerinden Türkiye-AB ilişkilerine dair bir genel değerlendirme yapılmaktadır.

\section{18 Mart Mutabakatının İçeriği ve Uygulaması}

2015 yılında, özellikle Avrupa'ya yakın coğrafyadaki ülkelerde yaşanan çatışmalar ve iç savaşlar nedeniyle milyonlarca insanın evlerini terk ederek, Avrupa ülkelerine ulaşmaya çalışmalarıyla yakın tarihin en büyük göç krizi 
ortaya çıkmıştı. ${ }^{2}$ Uluslararası Göç Örgütü verilerine göre 2015 yılında, Akdeniz yoluyla Avrupa ülkelerine geçen düzensiz göçmen sayısı bir önceki yıla göre 5 kat artışla, 1 milyon insanı geçmiş, Yunanistan üzerinden geçişler 885.000'e ulaşmıştı. ${ }^{3} 2015$ y1lı ayrıca 3.771 kişinin bu güzergâhta can vermesiyle en yüksek kaybın olduğu yıl olmuştu. ${ }^{4}$

Türkiye ise 2015 yılında, başta Suriye'deki çatışmalar nedeniyle ülkeye gelenler olmak üzere 2,5 milyon mülteciye kapılarını açarak dünya çapında en çok mülteciye ev sahipliği yapan ülke olmuştu. Aynı dönemde Almanya Şansölyesi Merkel'in Almanya sınırlarını sığınmacılara açma kararıyla birlikte, Ekim 2015 itibariyle Türkiye üzerinden Yunan adalarına geçen düzensiz göçmen sayısı günlük 7.000 kişiye çıkmıştı. Bu göç akımını kontrol altına almak amacıyla, Türkiye ile AB arasında müzakereler başlamış, 29 Kasım 2015 ve 7 Mart 2016 tarihlerinde taraflar arasında iki toplantı düzenlenmiş, 29 Kasım toplantısı sonrası "Ortak Göç Eylem Planı” kabul edilmiş, ancak düzensiz göçmen sayısında arzu edilen azalmanın gerçekleşmemesi üzerine 18 Mart 2016 tarihli Türkiye-AB Zirvesinde "Türkiye-AB Zirvesi Bildirisi" üzerinde anlaşmaya varılmıştır. ${ }^{5}$ Mutabakat ile "Ege'de göçmen ölümlerinin önlenmesi, insan kaçakçıllğı zincirinin kırılması ve yasadışı göçün yasal göçle ikame edilmesi”" amaçlanmış, alınacak tedbirler ile bu güzergâhın insan kaçakçıları ve düzensiz göçmenler için caydırıcı olması hedeflenmiştir.

Söz konusu metni Türk tarafı genel olarak "18 Mart Mutabakatı" olarak adlandırırken, AB tarafi genellikle "AB-Türkiye Bildirisi" olarak isimlendirmektedir. 18 Mart Mutabakatı, pek çok unsuru itibariyle 29 Kasım Ortak Açıklaması ve Ortak Eylem Planı'nı üzerine inşa edilmekle birlikte, daha somut tedbirler içermiştir. Mutabakatın en önemli unsuru düzensiz göçün önlenmesi amaciyla "1'e 1" formülünün hayata geçirilmesi olmuştur. Mutabakata göre, 20 Mart 2016 tarihi itibarıyla Türkiye'den Yunan adalarına geçen tüm yeni düzensiz göçmenler Türkiye'ye iade edilecektir. 20 Mart 2016 tarihinden itibaren Türkiye'den Yunan Adaları'na geçen her bir

2 https://reliefweb.int/report/world/unhcr-global-trends-forced-displacement-2015 Erişim Tarihi: Haziran 2021.

3 European Commission, EU-Turkey Statement One Year On, 2017.

4 https://www.iom.int/news/iom-counts-3771-migrant-fatalities-mediterranean-2015 Erişim Tarihi: Haziran 2021

5 European Council, EU-Turkey Statement (18 March 2016).

6 https://www.mfa.gov.tr/turkiye-ab-arasinda-18-mart_ta-varilan-mutabakata-iliskin-sorucevaplar.tr.mfa Erişim Tarihi: Haziran 2021. 
düzensiz göçmenin Türkiye'ye iadesi karşıllğında, AB'nin Türkiye'de yerleşik bir Suriyeliyi $A B$ üyesi ülkelerden birine yerleştirmesi öngörülmüştür. Mutabakat kapsamında ayrıca, Türkiye'deki geçici koruma altındaki Suriyelilerin insani ihtiyaçlarının giderilmesine yönelik olarak bir Sığınmacı Mali İmkânının (FRIT) (3+3 Milyar Avro) tesis edilmesi, düzensiz geçişler ciddi ölçüde azaldığında AB'nin Gönüllü İnsani Kabul Programı başlatarak bu kapsamda üye ülkelerin Türkiye'den Suriyeli kabul etmesi kararlaştırılmıştı.

Türkiye'nin AB'ye yönelik kitlesel göç akınını kontrol altına almaya yönelik çabaları karşıllı̆ında, AB'nin de bazı alanlarda adım atması konusunda anlaşmaya varılmıştı. Buna göre, Vize Serbestisi Diyaloğunun hızlandırılması ve Türkiye'nin Vize Serbestisi Yol Haritası yükümlülüklerini yerine getirmesinin ardından Haziran 2016 sonu itibarıla Türk vatandaşlarına vizelerin kaldırılması, katılım müzakerelerine hız kazandırılması, Gümrük Birliği'nin güncellenmesi çalışmalarına devam edilmesi, terörizm ile mücadelede Türkiye ve $\mathrm{AB}$ 'nin birbirine desteğini sürdürmesi öngörülmüştür.

18 Mart Mutabakatında alınan tedbirler özellikle caydırıcı niteliği ile düzensiz geçişlerin önüne geçebilmiştir. $\mathrm{AB}$ Komisyonu'nun tabiriyle oyun değiştiren (game changer) Mutabakat ilk yılında etkisini hemen göstermiş, AB Komisyonu verilerine göre düzensiz geçişler \% 97 oranında azalmıştı. ${ }^{7}$ Kaçakçıların kurduğu düzene indirilen darbe sayesinde, Ekim 2015'te günlük 10,000 kişiye ulaşan ortalama düzensiz geçişler, Mart 2017 itibariyle 43'e düşmüş, Ege'deki günlük ortalama ölümler ise 1,145 'ten 80 'e düşmüştü. Bugün de mutabakatın caydırıcı etkisi devam etmekte olup, ilk güne oranla düzenli geçişler ve ölümler oldukça düşük seviyede seyretmektedir. "1'e 1"uygulaması kapsamındaki geri alımlar ve AB ülkelerine yerleştirmeler sınırlı sayıda kalmışsa da, 18 Mart Mutabakatının esas başarısı Ege Denizi üzerinden yeni düzensiz göçleri engellemedeki caydırıcı etkisi olmuştur.

Mutabakat çerçevesinde Yunan adalarından Türkiye'ye yapılacak iade işlemlerinin $\mathrm{AB}$ hukukuna ve uluslararası hukuka uygun şekilde gerçekleştirileceği, hiçbir surette toplu sınır dışı etme işlemi olmayacağı, tüm göçmenlerin, ilgili uluslararası standartlar uyarınca ve "geri göndermeme"

7 European Commission, EU-Turkey Statement One Year On, 2017. 
ilkesine uygun olarak korunacağı, işlemlerin Birleşmiş Milletler Mülteciler Yüksek Komiserliği (BMMYK) ile işbirliği içinde gerçekleştirileceği belirtilmişse de Mutabakat ciddi eleştirilere maruz kalmıştır. ${ }^{8}$ Mutabakatı eleştiren çevreler, Türkiye'nin 1951 Cenevre Sözleşmesine koyduğu coğrafi kısıtlama nedeniyle Avrupa ülkeleri dışındaki ülkelerden gelenlerin Türkiye'de mülteci statüsüne başvurma haklarının bulunmadığı, Suriyelilere verilen geçici koruma statüsü nedeniyle mültecilerin yararlanacağı haklardan mahrum kalacakları, Türkiye'nin geri göndermeme ilkesine riayet etmeyeceği, dolayısıyla Türkiye'nin güvenli üçüncü ülke veya ilk iltica ülkesi olarak değerlendirilemeyeceği ve bunun sonucu olarak AB'nin Türkiye'ye hukuksuz iadeler yapacağı iddialarıyla, Mutabakatın AB hukuku ve uluslararası hukuka aykırı olduğunu ileri sürmüsslerdir.

AB tarafı bu iddiaları bertaraf etmek için bir takım adımlar atmıştır. Türkiye'den çeşitli güvenceler istemiş ve bunun neticesinde Türkiye, ilgili Geçici Koruma Yönetmeliğini değiştirerek iade edilen Suriyelilerin tekrar geçici koruma altına alınmasını sağlamıştır. Ayrıca, Yunanistan'dan Türkiye'ye toplu iade yapılacağı iddialarını bertaraf etmek için Yunan adalarında başvuruların bireysel olarak değerlendirilmesini sağlamak üzere AB uzmanlarının görevlendirilmesi, Yunan iltica kanunun değiştirilmesi, Yunanistan'a AB'den mali destek verilmesi gibi bazı tedbirler alınmıştır.

Buna ilaveten, bizzat $\mathrm{AB}$ Komisyonu tarafindan Türkiye tarafından verilen şartlı mülteci statüsünün Cenevre Sözleşmesi ile uyumlu şekilde koruma sağladığ 1 değerlendirmesi dahi yapılmıştır. AB Komisyonu'nun, 10 Şubat 2016 tarihli Göç Gündemi kapsamında alınan tedbirlerin durumuna

8 Özellikle insan hakları ve göçmen hakları alanında çalışan STK.ların eleştirisine uğrayan mutabakat akademik çevrelerden de ciddi eleştirilere maruz kalmıştır. Literatür için bknz: Cannizzaro, Enzo. "Denialism as the Supreme Expression of Realism: A Quick Comment on NF v. European Council.” European Papers Vol.2 (2017): 251-257; Carrera, Sergio, Leonhard den Hertog ve Marco Stefan. "It wasn't me!: The Luxembourg Court Orders on the EU-Turkey Refugee Deal." CEPS Policy Insights (Nisan 2017); Den Heijer, Maarten ve Thomas Spijkerboer. "Is the EU-Turkey Refugee and Migration Deal a Treaty." $E U$ Law Analysis (Nisan 2016); Goldner Lang, Iris. "Towards 'Judicial Passivism' in EU Migration and Asylum Law?" (Mayıs 9, 2020). Idriz, Narin. "The EU-Turkey Deal in front of the Court of Justice of the EU: An Unsolicited Amicus Brief." Asser Policy Brief No.3 (2017); Matuşescu, Constanta. "Considerations on the Legal Nature and Validity of the EU-Turkey Refugee Deal." Union of Jurists of Romania Law Review (Aral1k 2016): 91101. Gatti, Mauro. "The EU-Turkey Statement: A Treaty that Violates Democracy." Blog of the European Journal of International Law. 18 April 2016; Kaya, Hülya, The EUTurkey Statement on Refugees: Assessing its Impact on Fundamental Rights. Cheltenham: Edward Elgar (2020). 
ilişkin tebliğinde "güvenli üçüncü ülkeler” başlığ1 altında, "2013/32/EU Direktifinde tanımlandığı üzere, bir ülkenin güvenli üçüncü ülke olarak tanımlanabilmesi için o ülkenin Cenevre Sözleşmesi çerçevesinde uluslararası koruma sağlaması gerekmektedir ancak o ülkenin Cenevre Sözleşmesi'ni coğrafi sınırlama olmadan onaylaması gerekmemektedir" ifadesi ile Türkiye işaret edilerek, bir nevi Türkiye'nin güvenli üçüncü olarak değerlendirilmesinin önü açılmıştır. ${ }^{9}$

Tüm bu rötuşlar Mutabakatı eleştirilerden kurtaramamış, özellikle içeriği ve usulüne yönelik eleştiriler nedeniyle hukuki niteliği tartışma konusu olmuştur. AB'nin ne ölçüde ve ne şekilde bu mutabakata taraf olduğu hususu tartışmaların odağında yer almıştı. Zira, AB kurumları hukuken sorumluluktan siyrilarak, Mutabakatın ABAD'ın yarg1 denetimine takılmaması için çaba sarf etmişlerdir. Hukuki tartışmalar Mutabakatın uluslararası bir anlaşma mı yoksa politik bir mutabakat mı olduğu ve $A B$ tarafını hangi aktörlerin temsil ettiği soruları üzerinde yoğunlaşmıştı. ABAD'ın 18 Mart Mutabakatına ilişkin kararı, bu soruların mercek altına alınması bakımından önem arz etmektedir.

\section{Avrupa Birliği Adalet Divanı'nın 18 Mart Mutabakatına İlişkin Kararı}

\section{A. ABAD Kararı}

18 Mart Mutabakatının AB hukukuna aykırı olduğu gerekçesiyle ABAD'a üç ayrı başvuru yapılmış olup, ABAD üç davayı da aynı gerekçelerle 28 Şubat 2017 tarihinde karara bağlamıştır. ${ }^{10}$ İki Pakistan ve bir Afganistan vatandaşı tarafindan ayrı ayrı yapılan başvurulara dair üç karar da aynı tarihte verilmiş olup, içerik olarak birbirleriyle aynıdırlar. Söz konusu kararlarda sadece başvuru sahiplerine ilişkin maddi olaylarda bir takım farklılıklar bulunmaktadır. Dolayısıyla, burada sadece bir karar irdelenecektir. ${ }^{11}$

${ }^{9}$ European Commission. Communication from the Commission to the European Parliament and the Council on the State of Play of Implementation of Priority Actions under the European Agenda on Migration COM(2016) 85 Final (10.2.2016) 18.

10 Case T-192/16 - NF v European Council, 28.02.2017; Case T-193/16 - NF v European Council, 28.02.2017; Case T-257/16 - NF v European Council, 28.02.2017.

11 Case T-192/16 - NF v European Council, 28.02.2017. 
Türkiye'den Yunanistan'ın Midilli adasına botla geçiş yapan Pakistan vatandaşı NF, Yunanistan' da sığınma başvurusunda bulunmuş, Türkiye-AB Mutabakatında yer alan "1'e 1" uygulaması kapsamında Türkiye'ye geri gönderilmemek için Mutabakatın AB hukukuna ve uluslararası hukuka aykırı olduğu gerekçesiyle $\mathrm{AB}$ Zirvesi aleyhine $\mathrm{AB} A \mathrm{D}$ 'da dava açmıştır.

ABAD kararını, konuyla ilgili görüşlerini sorduğu $A B$ Zirvesi, $A B$ Konseyi ve $\mathrm{AB}$ Komisyonu'nun yanıtları çerçevesinde şekillendirmiştir. $\mathrm{AB}$ Zirvesi 18 Kasım 2016 tarihli yanıtında, Türkiye ile AB arasında AB'nin İşleyişi Hakkındaki Antlaşmanın (ABİHA) 218. Maddesi veya Viyana Sözleşmesi uyarınca bir anlaşmanın yapılmadığını, 144/16 sayılı Basın Açıklaması ile yayımlanan AB-Türkiye Bildirisinin AB Zirvesi sonrasında, $A B$ üyesi ülkeler ve Türkiye arasında gerçekleştirilen uluslararası bir zirvenin ürünü olduğunu, nitekim basın açıklamasının PDF formatında "uluslararası zirve" ifadesinin yer aldığını, AB Zirvesi dâhil ABİHA'nın 263. Maddesi kapsamındaki aktörlerden hiçbirinin Mutabakatı kaleme almadığını, dolayısıyla davalı durumunda olmaması gerektiğini, metinde yer alan "AB Zirvesi üyeleri” ifadesinin $\mathrm{AB}$ üyesi ülkelerin Devlet ve Hükümet Başkanları olarak kabul edilmesi gerektiğini, yine metinde geçen "AB" ifadesinin ise kamuoyunun anlayabilmesi için kavramların basitleştirilmesi amacıyla yapıldığını, kısaltmaların ve sadeleştirmelerin bir basın açıklaması çerçevesinde değerlendirilmesi gerektiğini, nitekim mutabakatın bir basın açıklaması yoluyla duyurulduğundan sadece bilgilendirici mahiyette olduğunu, hukuki bir değeri olmadığı, içeriği ve hedefleri bakımından hukuken bağlayıcı bir anlaşma olmadığını, bunun AB üyesi ülkelerin Devlet ve Hükümet Başkanları ile Türkiye Cumhuriyeti Başbakanı arasında bir politik mutabakat olduğunu ifade etmiştir. ${ }^{12}$

AB Komisyonu ise 18 Kasım 2016 tarihinde ABAD'a ilettiği yanıtında metnin dilinden anlaşılacağı üzere, Türkiye-AB Mutabakatının hukuken bağlayıcı bir metin olmadığını, taraflar arasında yapılan siyasi bir düzenleme olduğunu ileri sürmüştür. Komisyon, Mutabakatın tarafi olarak ise üye ülkelerin Devlet ve Hükümet Başkanlarını, Zirve Başkanını ve Komisyon Başkanını saymıştır. ${ }^{13}$

AB Konseyi de 2 Aralık 2016 tarihli yanıtında, AB-Türkiye Bildirisini kaleme almadığını, üye ülke temsilcileri ile Türkiye Cumhuriyeti arasındaki

12 ibid, para. $27 \& 28$.

13 ibid, para. 29. 
diyaloga hiçbir şekilde taraf olmadığını, Daimi Temsilciler Komitesi olan COREPER'de yapılan hazırlıkların sadece AB Zirvesi toplantılarına hazırlık mahiyetinde olduğunu, AB Konseyinin 18 Mart toplantısının hazırlıklarında yer almadığını belirtmiş, $A B$ Zirvesinin görüşünü teyiden $A B$ ve Türkiye arasında bir anlaşma yapılmadığını ifade etmiştir. ${ }^{14}$

Başvuru sahibi ise, metinde yer alan "anlaştlar" (agreed), "kararlaştırdılar" (decided), "teyit ettiler" (reconfirmed) ifadelerinin tarafların üstlendikleri yükümlülüklere işaret ettiğini, bu yükümlülüklerin uygulamaya dönük taahhütler içerdiğini, dolayısıyla metnin üçüncü şahıslara hukuki etkiler doğuran bir anlaşma olarak belirdiğini, ayrıca metinde " $A B$ Zirvesinin üyeleri” ifadesinin kullanılmış olması nedeniyle AB'nin sorumluluktan kaçamayacağını, nitekim $\mathrm{AB}$ üyesi ülkelerin kolektif olarak hareket ettiğini, ayrıca $\mathrm{AB}$ Komisyonu'nun 16 Mart 2016 tarihli Bildiriminden anlaşılacağı üzere $A B$ Zirvesi ve $A B$ Komisyonu'nun Mutabakatın hazırlanmasında ve müzakerelerinde aktif bir rol aldıklarını ve dolayısıyla Mutabakatın uluslararası anlaşma niteliği taşıdığını ileri sürmüştür. ${ }^{15}$

ABAD, 144/16 nolu Basın Açıklaması olarak yayımlanan bildirinin uluslararası hukuk ve $\mathrm{AB}$ hukukuna aykırılığını inceleyebilmek için bunun AB ile Türkiye arasında bir anlaşma olup olmadığını değerlendirmiştir. Lizbon Antlaşması ile bir $\mathrm{AB}$ Kurumu olan $\mathrm{AB}$ Zirvesinin hukuken bağlayıcı işlemler yapmasının mümkün olduğunu, Mutabakatın ismi ve şeklinden bağımsız olarak uluslararası anlaşma niteliği taşıyabileceğini ifade etmiştir. ABAD, sonraki aşama olarak Mutabakatın AB Zirvesi ile Türkiye arasında mı, yoksa üye ülke Devlet ve Hükümet Başkanları ile Türkiye arasında mı yapıldığını ele almıştır.

ABİHA'nın 263. Maddesi uyarınca ABAD, Konsey, Komisyon ve Avrupa Merkez Bankası'nın tasarruflarının ve Avrupa Parlamentosu'nun ve AB Zirvesi'nin üçüncü kişiler bakımından hukuki etki doğurması amaçlanan tasarruflarının hukuka uygunluğunu denetler. Ancak ABİHA'nın 263. Maddesi kapsamında üye devletlerin veya temsilcilerinin tasarrufları ABAD'ın yargı yetkisinde değildir. Dolayısıyla, bu noktada ABAD'ın ele aldığı husus Mutabakatın AB Zirvesinin bir tasarrufu olup olmadığı hususu olmuştur.

14 ibid, para.30

15 ibid, para.41. 
ABAD, 18 Mart 2016 tarihli toplantının Kasım 2015'ten itibaren yapılan üçüncü toplantı olduğunu, 29 Kasım 2015 ve 7 Mart 2016 tarihli toplantılara üye ülke temsilcilerinin, AB Zirvesi üyeleri olarak değil, Devlet ve Hükümet Başkanları sıfatlarıyla katıldıklarını tespit etmiştir. Nitekim, ilk toplantı sonrasında yayımlanan Basın Açıklamasının başlığının "Devlet ve Hükümet Başkanlarının Türkiye ile toplantısı, AB-Türkiye Bildirisi”, ikinci toplantı sonrası yayımlanan basın açıklamasının başlığının da "AB Devlet ve Hükümet Başkanlarının Açıklaması" olduğu ifade edilmektedir. Bununla birlikte, 18 Mart 2016 tarihli 144/16 sayılı Basın Açıklamasının önceki iki açıklamadan farklılık arz ettiği, açıklamada metnin AB Zirvesi üyeleri ile Türk meslektaşları arasında gerçekleştirilen toplantının sonucu olduğu, $\mathrm{AB}$ ile Türkiye'nin açıklamada yer alan hususlar üzerinde mutabık kaldıklarının ifade edildiği vurgulanmaktadır. $\mathrm{ABAD}$, metinde yer alan " $\mathrm{AB}$ Zirvesinin üyeleri” ve $A B$ ifadelerinin belirsizlik taşıdığ 1 tespitini yaparak Zirveye ilişkin diğer belgeleri değerlendirmenin doğru olacağını ifade etmiştir.

AB Zirvesi savunmasında, başta Zirve toplantısının 17-18 Mart tarihleri için iki gün olarak öngörüldüğünü, daha sonra göç krizinin derinleşmesiyle ikinci günkü toplantının $\mathrm{AB}$ üyesi ülkelerin Devlet ve Hükümet Başkanları ile Türkiye Cumhuriyeti Başbakanı arasında yapılmasının kararlaştırıldığını, bu ikinci toplantının güvenlik, personel ve masraflar gibi pratik/ lojistik nedenlerle ayn yapıldığını ifade etmiştir. ${ }^{16} \mathrm{AB}$ Zirvesi, bu argümanlarına kanıt olarak ilgili kurumların toplantı katılımcılarına gönderdikleri davetiyeleri ve toplantı programlarını ABAD’a sunmuştur.

ABAD, Konsey tarafindan sunulan belgeleri inceleyerek, 18 Mart tarihinde ilk olarak $\mathrm{AB}$ Zirvesi toplantısının yapıldığını, daha sonra $\mathrm{AB}$ üyesi ülkelerin Devlet ve Hükümet Başkanları ile Türkiye arasında bir toplantı yapıldığını, bu iki toplantının hukuken, şeklen ve organizasyon açısından farklı iki toplantı olduğu sonucuna ulaşmıştır. Mutabakat metnindeki ifadelerin belirsizliğine rağmen ikinci toplantıda üye ülke temsilcilerinin Hükümet ve Devlet Başkanları sıfatıyla toplantıda yer aldıklarını, AB Zirvesi Başkanının ve Komisyon Başkanının bu toplantıda bulunmalarının bunu $\mathrm{AB}$ Zirvesinin bir toplantısı yapmayacağını ifade etmiştir. Nitekim, AB Zirvesi Başkanı Tusk'ın esas itibariyle Türkiye ile müzakereleri koordine etmek üzere, $\mathrm{AB}$ Komisyonu Başkanı Juncker’in de

16 ibid, para.63. 
Komisyon tarafindan Ekim 2015'te başlayan teknik çalışmaların devamını sağlamak üzere toplantıda yer aldıklarını ifade etmiştir.

AB Zirvesi, AB Konseyi ve AB Komisyonu'nun savunmalarını temel alan ABAD, 18 Mart Mutabakatının hukuki etkileri olan uluslararası bir anlaşma olsun veya olmasın $\mathrm{AB}$ Zirvesi ile Türkiye arasında değil, üye ülkeleri temsil eden Devlet ve Hükümet Başkanları ile Türkiye arasında gerçekleştirildiği, $\mathrm{AB}$ Zirvesi'nin mutabakata taraf olmadığından ABİHA'nın 218. Maddesi kapsamında AB'yi bir taahhüt altına sokmadığg sonucuna varmış, ABİHA'nın 263. Maddesi uyarınca üye ülkeler tarafından yapılan uluslararası bir anlaşma yargı yetkisinde olmadığı için davayı reddetmiştir.

Bilahare davacılar kararı temyiz etmişler, ABAD 12 Eylül 2018 tarihli kararıyla $\mathrm{AB}$ hukuku açısından açıklık ve kesinlikten yoksun olduğu gerekçesiyle temyiz başvurusunu reddetmiş, konu bir bakıma $\mathrm{AB}$ hukuku açısından rafa kaldırılmıştır. ${ }^{17}$

\section{B. ABAD Kararının Değerlendirilmesi}

ABAD 18 Mart Mutabakatına ilişkin kararında, metnin içeriğinden ve uluslararası anlaşma niteliği taşıyıp taşımamasından ziyade, mutabakata $\mathrm{AB}$ bakımından hangi aktörlerin taraf olduğu üzerinde yoğunlaşmıştır. Mutabakatın $\mathrm{AB}$ adına kimin tarafından yapıldığını belirlerken ABAD, görüşünü metnin yapıldığı bağlam ve içeriğinden ziyade kendileri zaten taraf olmaktan kaçınmaya çalışan davalıların tezlerine dayandırmış ve 18 Mart Mutabakatını AB üyesi ülkelerin Devlet ve Hükümet Başkanlarının Türkiye ile akdettiği bir metin olarak kabul etmiştir. AB kurumlarının ABAD'a verdiği savunmalarında yer alan inandırıcılıktan uzak ifadeler ve ABAD'ın kararını bu iddialara dayandırmış olması $\mathrm{AB}$ açısından son derece düşündürücüdür.

Kararda, 17 Mart tarihinde yapılan AB Zirvesinin ilk başta iki gün olarak öngörüldüğünü ancak toplantının bir günde tamamlanması üzerine, Türkiye-AB toplantısının ertesi gün aynı binada, yani $\mathrm{AB}$ Konseyi binasında yapıldığı ifade edilerek, bunun maliyet, güvenlik ve etkinlik gerekçeleriyle bu şekilde düzenlendiği iddia edilmektedir. ABAD, ayrıca basın açıklamalarında geçen $\mathrm{AB}$ ifadesinin ve basın açıklamalarının Avrupa

17 Joined Cases C-208/17 P to C-210/17 P, NF v European Council, 12.09.2018. 
Konseyi internet sitesinde yayımlanmasını da pratik gerekçelerle açıklamaktadır. Üye ülkelerin kendi girişimleriyle yaptıkları bir mutabakatta neden kendi imkânlarını değil de $\mathrm{AB}$ binası, personeli ve imkânlarını kullandıkları sorusu yanıtsız kalmaktadır. Öte yandan, iddia edildiği gibi AB Zirvesi Mutabakatın tarafı değil ise, Türkiye'nin tüm üye ülke Devlet ve Hükümet Başkanları ile bir araya gelmesine gerek yoktu; Türkiye ile göç alanında işbirliğine ihtiyacı olan ülkelerin toplantıya ve mutabakata katılımı yeterli olmalıyd.

18 Mart toplantısına Türkiye'nin yanı sıra sadece üye ülke Devlet ve Hükümet Başkanları değil, Konsey Başkanı Tusk ve Komisyon Başkanı Juncker de katılmıştır. ABAD, Konsey Başkanı ve Komisyon Başkanı'nın Türkiye ile yapılan toplantılarda yer almalarının koordinasyonu sağlamaktan ibaret olduğunu, orada bulunmalarının mutabakatın Türkiye ile $A B$ arasında yapıldığı anlamını taşımayacağı şeklinde inandırıcı olmayan bir argümanda bulunmuştur. $\mathrm{Bu}$ karar, Lizbon Antlaşmasıyla $\mathrm{AB}$ kurumu statüsü kazanan ve $A B$ Zirvesi Başkanı ile üye ülke Devlet ve Hükümet Başkanlarından oluşan AB Zirvesinin kimliğini sorgulayan bir karar olarak da değerlendirilebilir. Zira, üye devletler $\mathrm{AB}$ Zirvesi olarak başladıkları toplantıya daha sonra Devlet ve Hükümet Başkanları olarak katıldıklarını ileri sürerek $\mathrm{AB}$ Zirvesinin kimliğini çıkarları doğrultusunda kullanmışlardır.

ABAD'1n 18 Mart Mutabakatı kararında, AB kurumları ile üye ülkeler arasındaki yetki paylaşımı ilkesini düzenleyen 30 Haziran 1993 tarihli Avrupa Parlamentosu v. Avrupa Toplulukları Konseyi ve Avrupa Toplulukları Komisyonu kararına atıfta bulunduğu görülmektedir. ${ }^{18}$ İlgili davada, Avrupa Parlamentosu, Komisyon'un teklifiyle üye ülke temsilcilerinin Konsey'de gerçekleştirdikleri bir toplantıda gelişmekte olan bir ülkeye (Bangladeş) mali yardım sağlanması konusunda aldıkları kararın AP'nin bütçe yapımı yetkisinin ihlali olduğunu ileri sürerek, ABAD'a iptal başvurusunda bulunmuştur. $\mathrm{ABAD}, \mathrm{AB}$ üyesi olmayan üçüncü bir ülkeye verilecek insani yardım başlığının Birliğin münhasır yetki alanında bulunmadığı gerekçesiyle, üye ülke temsilcilerinin bu konuda almış oldukları karar hakkında yarg1 yetkisi bulunmadığını ifade ederek, davayı reddetmiştir. 1993 tarihli kararda ABAD'ın dava konusu olan başlığın AB'nin münhasır yetkisinde mi bulunup bulunmadığ sorusunu yanıtlayarak

18 Joined Cases C-181/91 and C-248/91, European Parliament v Council of the European Communities and Commission of the European Communities, 30.06.1993. 
sonuca ulaştığı görülüyor. ABAD 18 Mart Kararında 1993 tarihli söz konusu karara atıfta bulunmakla beraber, aynı ilkenin söz konusu karara uygulanmasından özellikle imtina etmektedir. ${ }^{19}$ Nitekim, ihtilaf konusu başlığın $A B$ 'nin münhasır yetki alanına girip girmediği hususundan ziyade kimin tarafindan yapıldığı hususuna odaklanılarak, AB Zirvesinin sorumluluktan sıyrılmasının sağlandığı görülmektedir. Oysa, ABAD öncelikle 18 Mart Mutabakatının AB'nin münhasır yetkisinde olup olmadığ hususunu belirleyip, kararını buna göre vermeliydi.

Nitekim, ABAD açıklamalarında 18 Mart öncesindeki iki zirveye atıfta bulunmayı tercih ederken, 18 Mart Mutabakatının esas hukuki çerçevesini oluşturan ve Türkiye Cumhuriyeti ile AB yetkilileri arasında Aralık 2013 tarihinde imzalanan Türkiye-AB Geri Kabul Anlaşmasın1 ${ }^{20}$ göz ardı etmektedir. ABAD'ın bu tercihinin altında, AB'nin münhasır yetkisinde yer alan bir başlıkta düzenleme yapıldığı gerçeğini göz ardı etme amacı yattı̆̆ söylenebilir.

18 Mart Mutabakat1, Yunanistan'daki göçmenlerin sığınma başvurularını topluca ve genel bir değerlendirmeyle Türkiye'ye iadesini öngördüğünden $\mathrm{AB}$ hukuku ve uluslararası hukuk açısından sorunlu olduğu farklı çevrelerce dile getirilmişti. Nitekim, Komisyon yetkilileri de, başından beri 18 Mart mutabakatının $\mathrm{AB}$ hukuku ve uluslararası hukuka aykırı olabileceği düşüncesiyle, mutabakatın ABAD'ın yargı yetkisine takılmasından kaygı duymaktaydılar. AB kurumlarının savunmalarını da bu düşünce etrafında savunmacı bir refleksle oluşturmaları şaşırtıcı değildir. Dolayısıyla AB Kurumlarının başından beri mutabakatın ABAD'a takılmaması için siyasi bir pozisyon aldıkları açıktır.

ABAD, AB'nın münhasır yetki alanında bir başlı̆ga ilişkin olarak üçüncü kişiler bakımından hukuki etki doğuran bir düzenlemenin müzakerelerine $28 \mathrm{AB}$ üyesi ülkenin, $\mathrm{AB}$ Zirvesi Başkanının koordinasyonunda, AB Komisyonu Başkanı'nın katılımıyla, AB Konseyi binasında gerçekleştirildiğini ve $\mathrm{AB}$ Konseyi'nin internet sitesinden kamuoyuna Türkiye- $\mathrm{AB}$ mutabakatı olarak yansıtıldığını kabul etmekle

19 Cannizzaro, Enzo. "Denialism as the Supreme Expression of Realism: A Quick Comment on NF v. European Council." European Papers Vol.2 (2017): 255.

20 "Türkiye Cumhuriyeti ile Avrupa Birliği Arasında İzinsiz İkamet Eden Kişilerin Geri Kabulüne İlişkin Anlaşma” 16 Aralık 2013 tarihinde taraflarca imzalanmış olup, 1 Ekim 2014 tarihi itibarıla yürürlüğe girmiştir. https://www.resmigazete.gov.tr/ eskiler/2014/08/20140802-1.htm, Erişim Tarihi: Haziran 2021. 
beraber, AB'nin Mutabakata taraf olmadığını söyleyerek inandırıcı olmayan bir karara imza atmıştır. Oysa ABİHA'nın 263. Maddesi uyarınca, ABAD, Konsey ve Komisyon'un tasarruflarının ve $\mathrm{AB}$ Zirvesi'nin üçüncü kişiler bakımından hukuki etki doğurması amaçlanan tasarruflarının hukuka uygunluğunu denetler. ABAD'ın hukuki bir yaklaşımdan ziyade $A B$ kurumlarını hukuki sorumluluktan kurtarma amacıyla tezlerini oluşturduğu ve böylelikle AB Zirvesi'nın süreçteki dahlini ABİHA'nın 263. Maddesinde öngörülen yargı denetiminden kurtarmayı amaçladığı açıktır. Nitekim, Mutabakatın bir AB Kurumu tarafından akdedildiği sonucuna varılsaydı, uluslararası bir anlaşma yerine politik bir mutabakat olarak nitelendirilse dahi, ABİHA'nın 263. Maddesi uyarınca üçüncü kişiler bakımından hukuki etki doğurması amaçlanan bir tasarruf olduğundan ABAD'ın yarg1 denetimine takılması söz konusu olabilecekti.

ABAD'ın 18 Mart Mutabakatına ilişkin kararının AB'nin karar alma süreçleri bakımından önemli etkileri bulunmaktadır. Karar etraflıca incelendiğinde hukuki boşluklar ve çelişkiler içerdiği, zorlama bir karar olduğu açıktır. AB kurumları, 18 Mart Mutabakatıyla, "yaratıcı" bir şekilde kurucu antlaşmalardaki denge ve fren mekanizmalarını by-pass ederek, parlamenter denetim ve yargısal denetimin dışına çıkmışlar, ABAD da ilgili kararıyla bu kurumsal işbirliğine göz yummuştur. ABAD'ın, başvuru sahibinin mülteci hakları bakımından gündeme getirdiği sorunlu alanlardan kaçınmak için Mutabakatın AB Zirvesi tarafından yapılmadığı hükmüne vararak başını ağrıtmayacak bir yol seçtiği açıktır. ABAD'ın kararını uluslararası hukuk ve $\mathrm{AB}$ hukukunu görmezden gelen, reelpolitik bir refleksle alınmış bir karar olarak değerlendirmek yanlış olmayacaktır. ABAD'ın son dönemlerde siyasi hassasiyet içeren, özellikle göç ve iltica hukukunu ilgilendiren davalarda kasitlı olarak yetkilerini tam anlamıla kullanmayarak, bir tür "yargısal pasifizm" sergilediği ifade edilmektedir. ${ }^{21}$ Oysa, Lizbon Antlaşması'yla beraber Temel Haklar Şartının AB müktesebatının bir parçası olmasıyla birlikte, ABAD da temel hakların korunması anlamında bir nevi insan hakları mahkemesi niteliği kazanmıştı. Temel hakların koruyucusu olması gereken ABAD gibi üst düzey bir mahkemenin hukuk yerine reelpolitik bir yaklaşımla hareket etmesi şüphesiz hukukun üstünlüğü üzerinde yükselmesi gereken $\mathrm{AB}$ açısından talihsizlik olmuştur.

21 Goldner Lang, Iris. “Towards 'Judicial Passivism' in EU Migration and Asylum Law?" (2020). 


\section{18 Mart Mutabakatının Tarafları Kimdir?}

Mutabakatta $\mathrm{AB}$ tarafının hangi aktör tarafından temsil edildiği sorusu tartışmanın odağında yer almıştır. Esasında Mutabakatın ortaya çıkış şekli ve metinde yer alan ifadeler, $\mathrm{AB}$ tarafinın $\mathrm{AB}$ Zirvesi tarafindan temsil edildiğini açıkça göstermektedir. ABAD'ın 18 Mart Mutabakatına ilişkin kararındaki açılamalarda da görüldüğü üzere, 18 Mart Zirvesinden önceki iki toplantının tarafı olarak belgelerde Devlet ve Hükümet Başkanları ifadesi yer almakta iken, 18 Mart Mutabakatında bu ifade yerine açıkça $A B$ ve $A B$ Zirvesi üyeleri yer almaktaydı. Nitekim, Avrupa Parlamentosu'nda 13 Nisan 2016 tarihinde 18 Mart Mutabakatına ilişkin yapılan görüşmede AB Konseyi Başkanı Tusk'un kullandığı ifadeler dikkat çekicidir: "Mart ayındaki ilk Zirve'de liderler bir anlaşmaya varmak üzere Türkiye tarafindan önerilen teklifleri değerlendirip, ortak bir $\mathrm{AB}$ pozisyonu belirleme konusunda benden öncü olmamı istediler. 18 Mart AB Zirvesinde nihayet söz konusu anlaşma üzerinde mutabık kaldık". ${ }^{22}$ Tusk, bu sözleriyle Mutabakatın hazırlığında ve müzakerelerinde $\mathrm{AB}$ Zirvesinin rolünü açıkça itiraf ediyordu. Müzakereleri AB Zirvesi Başkanı yürütürken, toplantıda Komisyon Başkanı ona eşlik etmiş, $\mathrm{AB}$ Komisyonu da müzakerelerde ve mutabakatın sonlandırılmasında aktif rol almıştı. Nitekim, AB Komisyonu'nun 16 Mart 2016 tarihli Bildirimi Mutabakatın bir ön kopyası olarak belirmekte, Bildirimdeki ifadelerden AB Zirvesi ve AB Komisyonu'nun Mutabakatın hazırlanmasında ve müzakerelerinde aktif bir rol aldıklarını göstermektedir. ${ }^{23}$

Ancak, Mutabakatın hemen sonrasında temel haklara yönelik yoğun eleştirilerin ortaya çıkması ve bilahare ABAD'a getirilen iptal başvurusu, AB kurumlarının sorumluluktan kaçmalarına yol açmıştır. Oysa, AB'nin yetki alanındaki 18 Mart Mutabakatının tasarımı, müzakereleri, işleyişi ve bütçesinde doğrudan yer alırken, $\mathrm{AB}$ kurumlarının hukuken bu anlaşmayı üstlenmemesi ikna edici değildir.

Öte yandan, kamuoyu ile pek paylaşılmasa da 18 Mart'a giden müzakereler, dönemin Türkiye Cumhuriyeti Başbakanı Davutoğlu ile Almanya Şansölyesi Merkel ve AB Dönem Başkanı Hollanda Başbakanı

22 https://www.europarl.europa.eu/doceo/document/CRE-8-2016-04-13-ITM-005_EN.html? redirect Erişim Tarihi: Haziran 2021.

23 European Commission. Communication from the Commission to the European Parliament, the European Council and the Council: Next Operational Steps in EU-Turkey Cooperation in the Field of Migration, $\operatorname{COM(2016)166~Final~(16.3.2016).~}$ 
Rutte arasında gerçekleştirilmiş, ${ }^{24}$ bu görüşmelerde iki lider, AB'yi temsilen hareket etmiş ve Türk tarafına verilen taahhütler $\mathrm{AB}$ adına verilmişti. Aksi takdirde, Türkiye kendi adına hareket eden bir veya birden çok üye devletle AB'nin yetki alanına giren konularda müzakere edip, karşılıklı taahhütler içeren bir anlaşmaya varmazdı.

Mutabakatın uygulaması incelediğinde de AB'nin dahli teyit edilmektedir. Mutabakat sonrasında $\mathrm{AB}$ tarafindan yayımlanan muhtelif belgelerde ve $\mathrm{AB}$ yetkililerinin açıklamalarında açıcça Türkiye-AB mutabakatına atıfta bulunulmaktadır. Mutabakatın işleyişine bakıldığında, FRIT'in bir bölümü $\mathrm{AB}$ Bütçesinden finanse edilmiş, $\mathrm{AB}$ Komisyonu "1'e 1" uygulamasının işleyişi, FRIT, vizesiz seyahat, katılım müzakereleri, Gümrük Birliği’nin güncellenmesi başlıklarında Mutabakatı teknik anlamda izleme ve raporlama görevini üstlenmiştir. Nitekim, mutabakatın takibi için belli yapılar da oluşturulmuştur. Sözgelimi, mutabakat çerçevesinde AB tarafindan Türkiye'ye tahsis edilen 3+3 milyar Euro'luk fonun eşgüdümü için Sı̆̆ınmacı Mali İmkânı Yönlendirme Komitesi teşkil edilmiş olup, düzenli toplantılarına Türkiye'den ve Komisyon'dan yetkililerin katılımıyla devam etmektedir. Ayrıca, Komisyon tarafından düzenli olarak yayımlanmakta olan mültecilerin yeniden yerleştirilmesine ilişkin raporda üye ülkelerin Türkiye-AB mutabakatı çerçevesindeki yükümlülükleri izlenmektedir.

18 Mart Mutabakatının bağlamı ve metni objektif bir şekilde ele alındığında, Mutabakatın $\mathrm{AB}$ bakımından tarafının $\mathrm{AB}$ Zirvesi olduğu anlaşılmaktadır. Ancak, 18 Mart Mutabakatının AB açısından hangi aktör tarafindan akdedildiği sorusuna hukuki bir perspektiften yanıt verebilmek için $\mathrm{AB}$ ile üye devletler arasında Mutabakat kapsamındaki düzenlemelere ilişkin yetki paylaşımını irdelemek doğru olacaktır.

$\mathrm{ABAD}$, üye ülke temsilcilerinin söz konusu toplantıya $\mathrm{AB}$ Zirvesi üyeleri olarak değil Devlet ve Hükümet Başkanları sıfatlarıyla katıldıkları sonucuna vararak $A B$ 'nin yetki alanında yapılan bir düzenlemeyi üye ülkelerin yapabileceği hükmüne vararak bir yetki karmaşası yaratmıştır. Oysa, bu konuda ABİHA'nın hükümleri ve $A B A D$ içtihadı açıktır. ABİHA'nın 2. Maddesi uyarınca "Antlaşmaların Birliğe belirli bir alanda üye devletlerle paylaşılan bir yetki vermesi halinde (...) (ü)ye devletler,

24 https://www.aa.com.tr/tr/politika/basbakan-davutoglu-merkel-ve-rutte-ile-gorustu-/532685 Erişim Tarihi: Haziran 2021. 
yetkilerini, Birlik kendi yetkisini kullanmadığı ölçüde kullanırlar". ABİHA'nın 3. Maddesi ise "Bir uluslararası anlaşmanın akdedilmesi, Birliğin bir yasama tasarrufunda öngörülüyorsa veya Birliğin iç yetkisini kullanabilmesi için gerekliyse ya da Birliğin ortak kurallarını etkiliyor veya bunların kapsamını değiştiriyorsa, Birlik böyle bir anlaşmanın akdedilmesi konusunda münhasir yetkiye sahiptir" demektedir.

Bu noktada, AB'nin münhasır diş yetkisine ilişkin ilk kararlardan olan ABAD'ın 1971 tarihli ERTA kararında belirlenen Zımni Dış Yetki ilkesini vurgulamak gerekir. ${ }^{25}$ Komisyon, "Karayoluyla Uluslararası Taşıma Yapan Taşıt Mürettebatının Çalışmasına İlişkin Avrupa Anlaşması"nın (ERTA) üye devletlerce müzakere ve kabulüne ilişkin Konsey işlemlerinin iptali istemiyle ABAD'a başvuruda bulunmuş, ABAD da Birlik tarafından ortak politikanın uygulanması amacıyla ortak kurallar getiren bir düzenlemenin yapılmış olması durumunda, üye ülkelerin üçüncü devletlerle böyle bir düzenlemeyi etkileyecek nitelikte yükümlülük altına giremeyeceği, zira uluslararas1 anlaşma yapma yetkisinin sadece Birliğe ait olduğu hükmüne varmış, dolayısıyla Komisyon'un başvurusunu kabul etmiştir. ${ }^{26}$ Bir başka deyişle, ortak politika alanlarında, söz konusu kuralları etkileyecek nitelikte uluslararası anlaşma yapma yetkisi münhasıran Birliğe ait olduğundan üye ülkelerin bu alanlarda herhangi bir yükümlülüğe girmeleri yasaklanmıştır. Nitekim, ERTA kararı Lizbon Antlaşması ile yukarıda atıfta bulunulan ABIHHA'nın 3.Maddesi altında kurucu antlaşmalara dercedilmiş bulunmaktadır.

Öte yandan, paylaşılan yetki alanında ortak politikanın uygulanmasıyla ilgili Birlik tarafından bir düzenleme yapıldıysa, üye ülkelerin sadece uluslararası anlaşma yapma yetkisi değil, hukuki etkileri olan herhangi bir düzenleme yapmaları da yasaklanmıştır. Nitekim ABAD, 2009 tarihli AB Komisyonu v. Yunanistan davasında, Yunanistan'ın Uluslararası Denizcilik Örgütüne sunduğu teklifin dahi ileride hukuki yükümlülükler doğurabileceği gerekçesiyle Yunanistan'ın kurucu antlaşmaların ilgili hükümlerini ihlal ettiğini tespit etmiştir. ${ }^{27}$

25 Case C-22/70, Commission v. Council, 31.03.1971.

26 Bayraktaroğlu Özçelik, Gülüm. “Avrupa Topluluğunun Milletlerarası Özel Hukuk Alanında Uluslararası Anlaşma Akdetme Yetkisi ve C-01/03 Sayılı VE 7 Şubat 2006 Tarihli Avrupa Toplulukları Adalet Divanı Görüşü.” Ankara Üniversitesi Hukuk Fakültesi Dergisi 57:2 (2008): 30.

27 Case C-45/07, Commission v. Greece, 12.02.2009. 
ABİHA'nın 78. Maddesi ve 79. Maddesi uyarınca 18 Mart Mutabakatının düzenlediği göç, iltica ve sınır yönetimi başlıkları olağan yasama usulüne tabi olduğundan ve $\mathrm{AB}$ daha önce bu alanda Türkiye ile Geri Kabul Anlaşması akdettiğinden, üye ülkelerin $\mathrm{AB}$ için hukuki, idari veya mali bir sonuç doğuran böyle bir mutabakat üzerinde Türkiye ile anlaşmaları hukuken mümkün değildir. Nitekim, ABİHA'nın 3. Maddesi ve ABAD'ın 1971 tarihli ERTA kararı uyarınca ortak kurallar getirilmiş olan alanlarda, söz konusu kuralları etkileyecek nitelikte uluslararası anlaşma yapma yetkisi münhasıran Birliğe ait olduğundan, üye ülkelerin bu alanlarda herhangi bir yükümlülüğe girmeleri yasaklanmıştır. Ayrıca, ABAD'ın Yunanistan'ın Uluslararası Denizcilik Örgütüne sunduğu teklife ilişkin kararında da belirtildiği üzere ortak kurallar getirilmiş olan alanlarda üye devletlerin sadece uluslararası anlaşma akdetmeleri değil hukuki bağlayıcılığı olan herhangi bir düzenleme yapmaları da yasaklanmıştır. Dolayısıyla, Mutabakat bir uluslararası anlaşma olarak kabul edilmese dahi, üye devletlerin bu alanda bir düzenleme yetkileri bulunmamaktadır. Oysa, 18 Mart Mutabakatı ile üye ülkeler hâlihazırda AB-Türkiye Geri Kabul Anlaşması gibi bir $\mathrm{AB}$ düzenlemesinin bulunduğu bir alanda $\mathrm{AB}$ adına taahhüt altına girmiştir. Nitekim, Yunanistan'ın mutabakatın işleyişine yönelik olarak iltica yasasında gerçekleştirdiği düzenlemeler de, AB-Türkiye Geri Kabul Anlaşmasının işleyişini ilgilendiren düzenlemeler olarak belirmektedir. $^{28}$

Mutabakatın diğer unsurlarından Türk vatandaşlarına yönelik vize serbestleştirme süreci de ABİHA'nın 77. Maddesi uyarınca olağan yasama usulüne tabi olduğundan ve bu konuda $\mathrm{AB}$ Türkiye ile vize serbestleştirme sürecini 2013 yılında başlattığından üye ülkelerin bu konuda da bir düzenleme yapma yetkileri bulunmamaktadır. FRIT ise 24 Kasım 2015 tarihli Komisyonu Kararı ile kurulmuş bir fon olup, ${ }^{29}$ üye ülkelerin bu konuda resen karar vermeleri mümkün değildir. Katılım müzakerelerinin hızlandırılması ve Gümrük Birliği’nin güncellenmesine ilişkin hükümler de benzer şekilde $\mathrm{AB}$ 'nin yetki alanına girdiğinden, üye ülkelerin bu konularda

28 İltica Hizmetlerinin Organizasyon ve Operasyonuna İlişkin 4375 sayılı Kanun, 3 Nisan 2016 tarihli Yunanistan Resmi Gazetesinde yayımlanmıştır. https://www.refworld.org/docid/573ad4cb4.html Erișim Tarihi: Haziran 2021.

29 Official Journal of the European Union, Commission Decision of 24 November 2015 on the coordination of the actions of the Union and of the Member States through a coordination mechanism - the Refugee Facility for Turkey (8.12.2015). 
herhangi bir düzenleme yapmaları mümkün değildir. 18 Mart Mutabakatının uluslararası anlaşma niteliğini haiz olup olmamasından bağımsız olarak üye ülkelerin bu alanlarda herhangi bir hukuki etki yaratan düzenleme yapmaları mümkün değildir. Üye devletlerin Mutabakatın tarafı olduğu kabul edildiği takdirde, üye ülkeler açıkça $A B$ 'nin yetki alanını ihlal etmiş olmaktadırlar. Aynı zamanda AB Antlaşması'nın (ABA) 4. Maddesinde ifade bulan AB ve üye devletler arasında uyulması gereken "dürüst işbirliği" ilkesini de ihlal etmiş olmaktadırlar.

Mutabakatın AB Zirvesi değil de üye ülke devlet ve hükümet başkanları tarafından yapıldığı iddiası kabul edilse dahi, üye ülkeler aleyhine bir dizi hukuki işlem başlatılabileceğinden, mutabakat teoride de olsa yargı denetiminden kurtulamamaktadır. Mutabakata ilişkin olarak kurucu antlaşmalar çerçevesinde ABAD'da ihlal davası açılması söz konusu olabilirdi. Dolayısıyla AB kurumlarının sorumluluktan kurtulması, mutabakatı yargisal denetimden kurtarmayacaktı.

ABİHA'nın 258.Maddesi uyarınca “Komisyon, üye devletlerden birinin Antlaşmalar gereğince üzerine düşen bir yükümlülüğü yerine getirmediği kanısına varırsa, bu devlete kendi görüşlerini sunma imkânı tanıdıktan sonra, bu konuda gerekçeli görüşünü bildirir. İlgili devlet, Komisyon'un belirlediği süre içinde bu görüşe uygun hareket etmezse, Komisyon meseleyi ABAD'a götürebilir". Antlaşmaların bekçisi olan AB Komisyonu'nun üye ülkelerin yetki paylaşımını ihlal etmelerine karşı harekete geçmesi beklenirdi. Oysa, AB Komisyonu asli görevini ifa etmek bir yana Mutabakatın hayata geçirilmesi için çaba sarf etmiş, müzakerelerin her aşamasında ve mutabakatın uygulanmasında bizzat yer almıştı. Komisyon, bunun da ötesinde, mutabakatın işleyişi açısından önem arz eden Türkiye'nin "güvenli üçüncü ülke" olarak değerlendirilmesinin önünü açan bir yorum getirmişti. $\mathrm{AB}$ Komisyonu'nun başından beri Mutabakatın ABAD'ın yargı yetkisine takılmasından çekindiği ve bu nedenle ABAD'daki savunmasında da sorumluluktan kaçtığı düşünüldüğünde, üye ülkeler aleyhine $\mathrm{ABAD}$ nezdinde ihlal davası açmayacağı da açıktır.

Mutabakatın üye ülkeler tarafından yapılmış olduğu kabul edildiğinde, bunun ulusal mahkemelerin yargı denetimine açı olduğu da unutulmamalıdır. Dolayısıyla, Yunanistan veya başka bir üyenin ulusal mahkemelerine getirilecek bir dava ile pratikte $\mathrm{AB}$ ile Türkiye arasındaki düzenlemelerle işleyen mutabakatın bir kısım maddelerinin iptali söz konusu 
olabilecektir. Nitekim, 18 Mart Mutabakatı kapsamında bir kısım iade kararlarının Yunan mahkemelerine taşınması sonucunda, Suriyelilerin Türkiye'ye iadeleri çok yavaş ilerlemektedir. ${ }^{30}$

Öte yandan AP'de Mutabakatla ilgili görüşmeler yapıldıysa ve soru önergeleri verildiyse de, Parlamentonun da bu konuda suskun kalmış olması dikkat çekicidir. Oysa, AP Hukuk Servisi, mutabakatı uluslararası bir anlaşma olarak görmediğini, dolayısıyla 218. Madde'de yer alan usule uyulmasını beklemediğini, ancak mutabakatın tarafının AB Zirvesi olduğunu ifade etmiştir. ${ }^{31}$ Oysa, AP 18 Mart Mutabakatının hiçbir aşamasında bilgilendirilmemiştir. Bu şekilde Mutabakat, Parlamento'nun demokratik denetiminden de kurtulmuştur. $\mathrm{Bu}$ durumda, ABİHA'nın 263.Maddesi kapsamında $\mathrm{AB}$ Zirvesinin üçüncü kişiler bakımından hukuki etki doğuran bu tasarrufunu, Antlaşmalar'ın uygulanmasına ilişkin bir hukuk kuralının ihlali veya yetkinin kötüye kullanılması gerekçesiyle AP tarafından ABAD'ın önüne getirilebilirdi. AP, muhtemelen siyasi gerekçelerle, böyle bir başvuruda bulunmaktan imtina ederek, demokratik denetim yetkisini kullanmamıştır.

Sonuç olarak, AB Zirvesi Başkanı Tusk'ın ifadelerinden de anlaşılacağ üzere $A B$ tarafını, $A B$ Zirvesinin temsil ettiği açıktır. Nitekim AP'nin, mutabakatın tarafının $\mathrm{AB}$ Zirvesi olduğunu teyit etmiş olması dikkat çekicidir. Oysa AB Zirvesinin, mutabakatın konusu olan adalet, özgürlük ve güvenlik alanında bir yetkisi yoktur ve ABİHA'nın 218. Maddesi uyarınca uluslararası anlaşma akdetme yetkisi de bulunmamaktadır. 18 Mart Mutabakatının uluslararası anlaşma olmadığı kabul edilse dahi, AB Zirvesinin yetkisi dışında bir mutabakata taraf olması nedeniyle ABİHA'nın 263. Maddesi uyarınca üçüncü kişiler bakımından hukuki etki doğurması amaçlanan bir tasarruf olduğundan Mutabakatın ABAD'ın denetimine takılması söz konusu olacaktı. Zira, AB Zirvesinin Mutabakatın tarafı olduğu ABAD tarafından kabul edilse idi, ABAD metnin içeriğini incelemek durumunda kalacaktı ve insan hakları ve mülteci hakları açısından sıkıntılı olabilecek hususlar nedeniyle Mutabakatın iptali söz konusu olabilecekti.

30 European Commission, Turkey 2020 Report, SWD(2020) 355 final, (6.10.20202) https://www.ab.gov.tr/siteimages/trkiye_raporustrateji_belgesi_2020/turkey_report_2020.p df Erişim Tarihi: Haziran 2021.

$31 \mathrm{https} / /$ multimedia.europarl.europa.eu/en/committee-on-civil-liberties-justice-and-homeaffairs_20160509-1900-COMMITTEE-LIBE_vd, 20:06:20. 
Nitekim, Mutabakatı kurtarmak için AB Zirvesi de sorumluluktan kaçmış ve $\mathrm{ABAD}$ da bu gerçeği göz ardı ederek yargı denetimi görevini ifa etmemeyi tercih etmiştir.

Lizbon Antlaşması'yla olağan yasama usulünün Adalet, Özgürlük ve Güvenlik başlığı altındaki alanlara genişletilmesiyle, bu alanlarda Birlik yönteminin hâkim olması amaçlanmıştı. Göç, iltica, sınır yönetimi ve vize başlıklarına ilişkin hususları düzenleyen 18 Mart Mutabakatının AB kurumları tarafından sahiplenilmemiş olması ve ABAD tarafından üye ülkelerce yapıldığı hükmüne varılmış olması, AB'nin göç politikalarında Lizbonizasyon sürecine aykırı olarak, hükümetlerarasıcılığa bir geri dönüş olarak nitelendirilebilir. ${ }^{32}$

\section{18 Mart Mutabakatı Uluslararası Anlaşma mıdır?}

Mutabakat yapıldıktan dört gün sonra 22 Mart 2016 tarihinde AP, AB Konseyine yönelttiği sorularda, AB'nin münhasır ve paylaşılan yetki alanlarını düzenleyen hususlar içeren $\mathrm{AB}$-Türkiye Anlaşmasının bağlayıcı bir uluslararası anlaşma olup olmadığını, eğer bağlayıcı bir anlaşma ise neden ABİHA'nın 218. Maddesine uygun olarak müzakere edilmeden akdedildiğini, eğer bir anlaşma değilse Türk tarafının bu konuda bilgilendirilip bilgilendirilmediğini sormuştur. ${ }^{33} \mathrm{AB}$ Konseyi ve $\mathrm{AB}$ Komisyonu yanıtlarında 18 Mart Mutabakatının bir uluslararası anlaşma olmadığını ifade etmişlerdir. ${ }^{34}$ Nitekim 9 Mayıs 2016 tarihinde AP'nin Sivil Özgürlükler, Adalet ve İçişleri Komitesinde gerçekleştirilen toplantısında üyelere bilgi veren AP Hukuk Servisi temsilcisi, 18 Mart Mutabakatının bir uluslararası anlaşma olmadığını, politik bir mutabakat olduğunu, göç ve iltica alanına ilişkin metinde yer alan taahhütlerin daha önce akdedilmiş olan Türkiye-AB Geri Kabul Anlaşması ve Türkiye-Yunanistan Geri Kabul Anlaşmasını temel aldığını, dolayısıyla taraflara yeni bir taahhüt getirmediğini, $\mathrm{AB}$ Zirvesinin bu şekilde politik düzenlemelerde bulunabileceğini ifade etmiştir. ${ }^{35}$ Diğer $\mathrm{AB}$ kurumları gibi $\mathrm{AP}$ 'nin de

32 Carrera, Sergio, Leonhard den Hertog ve Marco Stefan. "It wasn't me!: The Luxembourg Court Orders on the EU-Turkey Refugee Deal." CEPS Policy Insights (2017) 8.

$33 \mathrm{https} / / / \mathrm{www}$.europarl.europa.eu/doceo/document/O-8-2016-000053_EN.html?redirect Erişim Tarihi: Haziran 2021.

34 Ekşi, Nuray. "18 Mart 2016 Tarihli AB-Türkiye Zirvesi Bildirisinin Hukuki Niteliği."Contemporary Research in Economics and Social Sciences 1 (2017): 73.

${ }^{35} \mathrm{https} / / /$ multimedia.europarl.europa.eu/en/committee-on-civil-liberties-justice-and-homeaffairs_20160509-1900-COMMITTEE-LIBE_vd, 20:06:20 Erişim Tarihi: Haziran 2021. 
mutabakatı uluslararası bir anlaşma olarak görmediği, dolayısıyla 218. Madde'de yer alan usule uyulmasını da beklemediği anlaşılmaktadır. Ancak, mutabakatın tarafının $\mathrm{AB}$ Zirvesi olduğunu teyit etmiş olması dikkat çekicidir. AP'nin pozisyonu önem arz etmektedir, zira AP kurucu antlaşmalar uyarınca uluslararası anlaşmaların akdedilmesinde yetkiye sahip olmasına rağmen 18 Mart Mutabakatı'nın hiçbir aşamasında yer almamış, buna rağmen konuyu ABAD'a taşımamıştır.

18 Mart Mutabakatının hukuken bağlayıcı nitelikte bir uluslararası anlaşma olup olmadığı konusu, özellikle metnin şekli, içeriği ve yürürlüğe konma usulü bakımından tartışma konusu olmuştur. Türkiye ve AB, 1969 tarihli Viyana Antlaşmalar Hukuku Sözleşmesine taraf değillerdir, ancak uluslararası örf ve adet hukukunun bir parçası olması nedeniyle Sözleşmeyi dikkate almak doğru olacaktır. ${ }^{36}$ Sözleşmenin 2. Maddesi antlaşmayı, "ismi ne olursa olsun devletler arasında yazılı olarak akdedilen ve uluslararası hukuka tabi olan uluslararası anlaşma" olarak tanımlamaktadır. En genel tanımıyla antlaşma "uluslararası hukukun kendilerine bu alanda yetki tanıdığı kişiler arasında uluslararası hukuka uygun bir biçimde, hak ve yükümlülükler doğuran, bunları değiştiren ya da sona erdiren yazılı irade uyuşması" 37 olarak tanımlanabilir. Viyana Sözleşmesi uyarınca bu yazılı irade uyuşmasının şekline ve adlandırmasına ilişkin özel bir koşul bulunmamaktadır. Nitekim, Uluslararası Adalet Divanı'nın 1 Temmuz 1994 tarihli Katar v. Bahreyn kararında Katar Dışişleri Bakanı, Bahreyn Dışişleri Bakanı ve Suudi Arabistan Dışişleri Bakanı arasında imzalanan toplantı zabıtları dahi uluslararası anlaşma olarak kabul edilmiştir. ${ }^{38}$ Uluslararası Adalet Divanı aynı kararında metnin anlaşma olup olmadığının belirlenmesinde, metnin şeklinin değil içeriğinin ve tarafların bağlanma niyetinin belirleyici olduğunu ifade etmiştir. Dolayısıyla, uluslararası anlaşma için belirleyici olan faktörler metnin içeriği, diğer bir deyişle tarafların hukuki taahhütte bulunup bulunmadıkları hususu ve tarafların bağlanma iradesi olarak belirmektedir. ${ }^{39}$ Metin ve bağlamı, bir yandan

36 Vienna Convention on the Law of Treaties (1969)

37 Pazarcı, Hüseyin. Uluslararası Hukuk. Turhan Kitabevi (2008): 43.

38 International Court of Justice, Case Concerning Maritime Delimitation and Territorial Questions Between Qatar and Bahrain (01.07.1994)

39 Karaca, Hüseyin Akif. "Türkiye-Avrupa Birliği Geri Kabul Antlaşması ve 18 Mart 2016 Tarihli Türkiye-Avrupa Birliği Zirve Bildirisi Uyarınca Düzensiz Göçle Mücadele ve Bazı Sorunlu Alanlar." Ankara Hacı Bayram Veli Üniversitesi Hukuk Fakültesi Dergisi 24 (2020): 181. 
yükümlülükler ve ödevler doğuran ifadeler içermeli, bir yandan da tarafların bağlanma niyetlerini ortaya koymalıdır.

18 Mart Mutabakatı değerlendirildiğinde, Viyana Sözleşmesinde belirtildiği üzere metnin adlandırması belirleyici olmadığından, mutabakatın bildiri ("statement") başlı̆g taşıması anlaşma niteliği yitirmesine neden olmamaktadır. Ayrıca, basın açıklaması olarak AB Konseyinin internet sitesi üzerinden kamuoyu ile paylaşılmış olması da şekli bir unsur olduğundan, bağlayıcı koşul değildir.

Metnin içeriği incelendiğinde, tarafların üçüncü kişiler açısından hukuki etki doğurması amaçlanan tasarruflar öngördükleri görülmektedir. Yalnız bu taahhütler dile getirilirken uluslararası hukuk açısından daha uygun olan ve yükümlülükleri vurgulayan "shall" ifadesi yerine bağlayıcıllı̆ı olmayan üstlenmelerde kullanılan, daha belirsiz bir anlam yükleyen "will" ifadesinin fiillerden önce kullanıldığı dikkat çekmektedir. Bununla beraber, üzerinde mutabık kalınan taahhütler irdelendiğinde, $\mathrm{AB}$ ve Türkiye'nin düzensiz göçü engellemeye "karar verdikleri" ("decided"), bu hedefe dönük olarak bir dizi madde üzerinde "anlaştıkları" ("agreed"), eylem planındaki taahhütlerini "teyit ettikleri" ("reconfirmed") görülmekte, bu kapsamda 20 Mart 2016 tarihinden itibaren Türkiye'den Yunan Adaları'na geçen her bir düzensiz göçmenin Türkiye'ye iadesi karşılığında, AB'nin Türkiye'de yerleşik bir Suriyeliyi $\mathrm{AB}$ üyesi ülkelerden birine yerleştirmesinin "kararlaştırıldı̆̆ı" ifade edilmektedir.

Metnin uluslararası anlaşma kimliğini açısından en önemli hususlardan biri üçüncü kişiler açısından hukuki etki doğuran yeni tasarruflar yaratmasıdır. 18 Mart Mutabakatının kabulünden hemen sonra, "1'e1" kuralının hayata geçirilmesi için taraflar gerekli hukuki ve fiili düzenlemeleri yapmışlardır. Nisan 2016'da Yunanistan, düzensiz göçmenlerin ve sığınmacıların başvuruların hızlandırılmış (fast-track) işlemlerle değerlendirilmesi ve bu kişilerin iadesi için bir yasa çıkarmış, ${ }^{40}$ söz konusu yasa açıkça Türkiye'yi güvenli üçüncü olarak ilan etmemiş olsa da, Türkiye'ye iadelerin yasal anlamda önünü açmıştır. ${ }^{41}$ Türkiye de 4 Nisan

40 İltica Hizmetlerinin Organizasyon ve Operasyonuna İlişkin 4375 sayılı Kanun

41 Lehner, Roman. "The EU-Turkey 'deal': Legal Challenges and Pitfalls." International Migration Vol.57(2) (2019):179. 
2016 tarihinden itibaren düzensiz göçmenleri fiilen kabul etmeye başlamış, ${ }^{42}$ tüm bu eylemler için gerekli altyapı, eleman ve finansman ihtiyacı karşılanmıştır. Düzensiz göçmenlerin iade işlemlerine ilişkin masraflar, $\mathrm{AB}$ tarafından karşılanmıştır. Ayrıca Mutabakat sonrasında 2016/1754 sayılı Konsey Kararı kabul edilerek, "1'e1" kuralının uygulanmasına yönelik olarak üye ülkelerin yeniden yerleştirme programları kapsamında Türkiye'den gönderilecek Suriyelilerin kabulüne dair bir düzenleme yapılmıştır. ${ }^{43}$ Konsey Kararının gerekçesinde 18 Mart Mutabakatına atıfta bulunulduğunu vurgulamak gerekir. Ayrıca, FRIT'in bir bölümü $\mathrm{AB}$ Bütçesinden finanse edilmiş, AB Komisyonu Mutabakatı teknik anlamda izleme ve raporlama görevini üstlenmiş, metinde yer alan taahhütlerin aylık olarak taraflarca izleneceği belirtilmiştir. Dolayısıyla, metnin taraflarca üstlenilen yükümlülükler içerdiği ve bilahare üçüncü şahıslara hukuki etkiler doğuran taahhütlerin hayata geçirildiği açıktır.

Tarafların bağlanma iradelerine ilişkin olarak ise, hem Türkiye'nin hem de AB'nin 18 Mart Mutabakatını imzalamadıkları görülmektedir. Viyana Sözleşmesinin 11. Maddesi tarafların bağlanma niyetlerini açıklama yolları olarak "imza, belgelerin teatisi, onay, kabul, tasvip veya katılma veya üzerinde mutabık kalındıysa diğer herhangi bir araçla açıklanabilir" demektedir. Dolayisiyla, metnin imzalanmadan yayımlanan bir bildiri olmasi uluslararası bir anlaşma olmasına engel değildir. Nitekim, Uluslararası Adalet Divanının 19.12.1978 tarihli Ege Kıta Sahanlığı Davasında "bir ortak bildirinin bir uluslararası anlaşma olmasını yasaklayan hiçbir uluslararası hukuk kuralı yoktur" denilerek, ortak bildirinin kabul edilebilir bir yöntem olduğu ifade edilmektedir. ${ }^{44}$

Buna ilaveten, tarafların mutabakatı kendi iç usullerine göre onaylamadıkları ve resmi gazetelerinde yayımlamadıkları görülmektedir. Viyana Sözleşmesinin 46. maddesinde yer alan "ihlal aşikâr ve iç hukukunun temel önemi haiz bir kuralı ile ilgili olmadığı sürece bir devletin, bir antlaşmayla bağlanma rızasının iç hukukunun antlaşma akdetme yetkisiyle

42 https://www.mfa.gov.tr/turkiye-ab-arasinda-18-mart_ta-varilan-mutabakata-iliskin-sorucevaplar.tr.mfa, Erişim Tarihi: Haziran 2021.

43 Council Decision (EU) 2016/1754 of 29 September 2016 amending Decision (EU) $2015 / 1601$ establishing provisional measures in the area of international protection for the benefit of Italy and Greece, OJ L 268/82, 1.10.2016.

44 International Court of Justice, Reports of Judgments, Advisory Opinions and Ordes Aegean Sea Continental Shelf Case (Greece v. Turkey) (Judgement of 19.12.1978) para. 96. 
ilgili hükümlerini ihlal etmek suretiyle açıklandığı vakıasına rızasını geçersiz kılan bir gerekçe olarak başvuramayacă̆ı" hükmü dikkate alındığında, iç usullerin yerine getirilmemiş olmasının Mutabakatın, uluslararası anlaşma olarak kabul edilmesini engellemeyeceği söylenebilir. ${ }^{45}$ Nitekim, uluslararas1 anlaşmaların bağlayıcı güç kazanması için ulusal onay süreçlerine girmeksizin, basit usul yoluyla onaylanması da mümkündür. ${ }^{46}$

Mutabakatın iç usul açısından gereken onaylanma işlemlerinin yapılmamış olması bir uluslararası anlaşma olarak kabul edilmesini engellemeyecek olsa da, bu noktada tarafların niyeti belirleyici olmaktadır. Nitekim, Uluslararası Adalet Divanının 1978 Ege Kıta Sahanlığı kararına göre, bir ortak bildirinin uluslararası anlaşma olarak nitelenebilmesi hazırlandığı koşullardan ve müzakere edildiği çerçeveden anlaşılabilecek olup, bu noktada tarafların bağlanma niyetlerinin olup olmadığı hususunun belirleyici olacağı vurgulanmaktadır. ${ }^{47} 18$ Mart Mutabakatının da uluslararası hukuk açısından en sorunlu yanının tarafların bağlanma iradelerinin eksikliği olduğu görülmektedir. Viyana Sözleşmesinin 26. Maddesinde ifade bulan "ahde vefa" (pacta sund servanda) ilkesi uyarınca, "her antlaşma ona taraf olanları bağlar ve tarafların onu iyi niyetle icra etmesi gerekir". Bu noktada tarafların, niyetini irdelemek gerekecektir.

Tarafların baştan beri bu mutabakatı uluslararası bir anlaşma olarak değil, daha ziyade politik bir düzenleme olarak benimsedikleri söylenebilir. Esasında, tarafların uluslararası bir anlaşmanın müzakereleri için gereken yetkilendirmeden ve onay için gerekli iç usullerden kaçınarak, hızlı hareket edebilmek için böylesi bir politik düzenlemeyi tercih ettikleri açıtır. Buna ilaveten, Mutabakatta kullanılan ifadelerin muğlaklığ 1 ve AB kurumlarının ABAD'a gönderilen savunmalarda bu muğlak ifadelerden yararlanarak ortaya koydukları argümanlar, özellikle AB'nin sorumluluktan kaçmak için zemin yarattığını ortaya koymaktadır.

$\mathrm{AB}$ tarafının mutabakat sonrası davranışları niyetini ortaya koymak açısından dikkat çekicidir. AB Zirvesi, AB Komisyonu ve AB Konseyi'nin ABAD'a sundukları savunmalarda uluslararası bir anlaşma şeklinde bir bağlanma niyetinde olmadıklarını ifade etmişlerdir. AB Zirvesi, ABAD'a

45 Den Heijer, Maarten ve Thomas Spijkerboer. "Is the EU-Turkey Refugee and Migration Deal a Treaty." EU Law Analysis (2016).

46 Pazarc1, Hüseyin. Uluslararası Hukuk. (2008): 57.

47 Karaca, Hüseyin Akif. “Türkiye-Avrupa Birliği Geri Kabul Antlaşması.” (2020): 182. 
sunduğu 18 Kasım 2016 tarihli yanıtında, Türkiye ile AB arasında AB'nin İşleyişi Hakkındaki Antlaşmanın (ABİHA) 218. Maddesi veya Viyana Sözleşmesi uyarınca bir anlaşmanın yapılmadığını, mutabakatın bir basın açıklaması yoluyla duyurulduğundan sadece bilgilendirici mahiyette olduğunu, hukuki bir değeri olmadığını, içeriği ve hedefleri bakımından hukuken bağlayıcı bir anlaşma olmadığını, bunun AB üyesi ülkelerin Devlet ve Hükümet Başkanları ile Türkiye Cumhuriyeti Başbakanı arasında bir politik mutabakat olduğunu ifade ederek $\mathrm{AB}$ tarafının niyetini açıkça ortaya koymuştur. ${ }^{48} \mathrm{AB}$ tarafının mutabakat kapsamındaki yükümlülüklerini yerine getirmekteki isteksizliği de niyetini ortaya koymak bakımından önem taşımaktadır. Zira $\mathrm{AB}$, “1'e 1" formülünün hayata geçirilmesi ve FRIT fonlarının aktarılması dışındaki yükümlüklerini yerine getirmemiştir. Türkiye'deki Suriyelilerin AB ülkelerine yerleştirilmesini öngören Gönüllü İnsani Kabul Programı hayata geçirilmemiş, Türk vatandaşlarına yönelik vize serbestleştirme süreci yarım kalmış, katılım müzakereleri ve Gümrük Birliği'nin güncellenmesinde de ciddi gelişme kaydedilememiştir. AB tarafından farklı olarak, Türk tarafının mutabakatın uluslararası anlaşma niteliğine dair açıkça bir tutumu olmamışsa da, en üst düzeyde yapılan açıklamalarda mutabakatın müteaddit kereler askıya alınma tehdidinin dile getirildiğini vurgulamak gerekir. Nitekim, Şubat 2020'de Türkiye, Avrupa'ya geçmek isteyen göçmenlere sınır kapılarını açtığını duyurarak mutabakatı bir nevi askıya almıştır. Daha sonra pandemi süreci ile sekteye uğrayan karşılıklı geri alımlar, Yunanistan'ın sığınmacılara uyguladığı geri itmelerle ciddi bir darbe almıştır.

Mutabakatın uygulanmasına ilişkin tarafların niyetleri ve özellikle AB'nin yaklaşımı dikkate alındığında, mutabakatın uluslararası bağlayıcı bir anlaşmadan ziyade koşullara göre şekillenen bir politik düzenleme şeklinde algılandığını söylemek yanlış olmayacaktır. Mutabakatın taraflar arasında bağlayıcı olmayan ancak siyasi bir düzenlemeyi öngören "bağlayıcıllı̆ı olmayan üstlenme" adı altında atipik bir anlaşma olarak nitelendirilebileceği düşünülmektedir. ${ }^{49}$

Öte yandan, 18 Mart Mutabakatının göçmenlerin iadesine ilişkin hususlarının hukuki çerçevesini Türkiye-AB Geri Kabul Anlaşması ve

48 ibid, para. $27 \& 28$.

49 Pazarcı, Hüseyin. Uluslararası Hukuk (2008): 44. 
Türkiye-Yunanistan Geri Kabul Anlaşması teşkil ediyordu. ${ }^{50} 1$ Ekim 2014 tarihinde yürürlüğe giren Türkiye-AB Geri Kabul Anlaşmasının üçüncü ülke vatandaşları ve vatansızların iadesi için öngörülen yürürlük tarihi 1 Ekim 2017 idi. 18 Mart Mutabakatı kapsamında Türk vatandaşlarına Haziran 2016 sonu itibarıyla vizelerin kaldırılması öngörüldüğünden, Türkiye'nin Vize Serbestisi Yol Haritası yükümlülüklerinden Geri Kabul Anlaşmasının üçüncü ülke vatandaşları için yürürlüğe konması da Ortak Geri Kabul Komitesi kararı ile 1 Haziran 2016 tarihine çekilmişti. ${ }^{51}$ Ancak daha sonra, mutabakat kapsamındaki taahhütlerden Türk vatandaşlarına vizesiz seyahatin gerçekleşmemesi Türkiye tarafından gerekçe gösterilerek, Temmuz 2019'da Geri Kabul Anlaşması askıya alınmıştı. ${ }^{52} \mathrm{Bu}$ durumda hukuken 18 Mart Mutabakatının uygulanması da durdurulmuş oluyordu. Buna rağmen, Mutabakatın göçmenler açısından uygulaması devam etmiş, 1'e 1 kapsamında alımlara devam edilmişti. Nitekim, AB Komisyonu yetkilileri de Mart 2021'de yaptıkları açıklamada mutabakatın halen geçerli olduğunu, uygulamada yaşanan sıkıntıların giderilmesi gerektiğini dile getirmişlerdir. ${ }^{53}$ Son beş yılda yapılan AB Zirve Sonuçlarında da "ABTürkiye Bildirisi”ne atıfta bulunularak, Mutabakatın devam ettiği teyit edilmektedir. Dolayısıyla AB'nin 18 Mart Mutabakatını, Türkiye-AB Geri Kabul Anlaşmasından bağımsız olarak değerlendirdiğini, bunun hukuki çerçevesini ihmal ederek Türkiye-AB arasında bir politik/idari bir mutabakat olarak kabul ettiğini söylemek yanlış olmayacaktır.

50 ABAD'ın göz ardı ettiği bu husus, AP Hukuk Servisi tarafından da teyit edilmiştir: https://multimedia.europarl.europa.eu/en/committee-on-civil-liberties-justice-and-homeaffairs_20160509-1900-COMMITTEE-LIBE_vd, 20:06:20. Ayrica bknz; Den Heijer, Maarten ve Thomas Spijkerboer. "Is the EU-Turkey Refugee and Migration Deal a Treaty." EU Law Analysis (Nisan 2016); Idriz, Narin. "The EU-Turkey Deal in front of the Court of Justice of the EU: An Unsolicited Amicus Brief." Asser Policy Brief No.3 (2017); Matuşescu, Constanta. "Considerations on the Legal Nature and Validity of the EU-Turkey Refugee Deal." Union of Jurists of Romania Law Review (Aralık 2016): 91-101. Gatti, Mauro. "The EU-Turkey Statement: A Treaty that Violates Democracy." Blog of the European Journal of International Law. 18 April 2016. Öztürk, Neva Övünç ve Cavidan Soykan. "Third Anniversary of EU-Turkey Statement: A Legal Analysis." Heinrich Böll Stiftung (Aralık 2019).

${ }^{51}$ Yürürlüğe girişi öne çeken bu kararın Anayasaya ve Geri Kabul Anlaşmasına aykırı olduğu iddia edilmektedir. Ekşi, Nuray. "18 Mart 2016 Tarihli AB-Türkiye Zirvesi Bildirisinin Hukuki Niteliğii"(2017): 57.

52 Dışişleri Bakanı Mevlüt Çavuşoğlu'nun Temmuz 2019'da yaptı̆̆ açıklamayla TürkiyeAB Geri Kabul Anlaşması Türkiye tarafından askıya alınmış, bu durum bilahare AB'ye yazılı olarak bildirilmiştir.

$53 \mathrm{https}: / /$ www.aa.com.tr/tr/dunya/ab-18-mart-mutabakatinin-yenilenmesini-isteyecek/ 2177028, Erişim Tarihi: Haziran 2021. 
AB Komisyonu, 18 Mart Mutabakatının sonrasında, üçüncü ülkelerle benzer düzenlemeler yapmayı öngören "Avrupa Göç Gündemi altında Üçüncü Ülkelerle Ortaklık Çerçevesi Kurulmasına ilişkin Komisyon Bildirisini" 7 Haziran 2016 tarihinde yayımlamıştır. ${ }^{54} 18$ Mart Mutabakatına atıfta bulunan Bildiri, temel olarak kaynak ve transit ülkelerden geri kabul ve iadeleri düzenlemeyi öngörmüştür. Söz konusu ülkelerle akdedilecek anlaşmaların (compact) ABİHA'nın 218. Maddesine tabi olmayan, hukuki statüsü belirsiz düzenlemeler olmasının öngörüldüğü anlaşılmaktadır. Nitekim, Ekim 2016'da AB ile Afganistan Hükümeti arasında göç konusunda imzalanan İleriye Doğru Ortak Yol (Joint Way Forward) Açıklaması da benzer bir düzenleme olarak ortaya çıkmış, AB Konseyi ve Parlamento'nun dahli olmadan gerçekleştirilmiştir. 18 Mart Mutabakatında olduğu gibi Almanya yine öncü bir rol üstlenmiş, Afgan mültecileri geri göndermeyi hedefleyen Almanya'nın baskısıyla Afganistan-AB Mutabakatı yapılmıştı. $A B$ ülkelerine gelen Afgan mültecilerin Afganistan'a iadesini öngören mutabakat, ABİHA'nın 218. Maddesindeki usullere tabi olmadan kısa yoldan yapılmış bir geri kabul anlaşması olarak adlandırılabilir. Nitekim $\mathrm{AB}$ adına hangi kurumun taraf olduğunun belli olmadığı açıklama metninde, Mutabakatın uluslararası hukuk açısından bağlayıcı olmadığı ifade edilmektedir. $^{55}$

AB'nin yaratıcı bir yöntemle kurucu antlaşmalardaki denge ve fren mekanizmalarını by-pass ederek resmi anlaşmalar yerine gayriresmi düzenlemelerle hareket ederek pratik ama hukuken sıkıntılı bir yolu tercih ettiğini söylemek yanlış olmayacaktır. Üçüncü ülkelerle yapılan anlaşmalara ilişkin bu yeni yaklaşım, geri göndermeme ilkesi (non-refoulement), kolektif sınır dışı etmenin önlenmesi, başvurunun değerlendirilmesi gibi mülteci haklarının göz ardı edilmesine yol açtığı ve kurucu antlaşmalardaki denge ve fren mekanizmalarını aşındırarak, demokratik denetimi ortadan kaldırdığ 1 iddiasıyla eleştirilmektedir. AB'nin özellikle güçlü üyelerden gelen baskıyla, şeffaf olmayan ve hukuki mekanizmalardan sıyrılarak gerçekleştirdiği bu "hukuki mühendislik" 56 ürünü düzenlemelerin, demokratik bir denetimden ari olduğu açıktır.

54 European Commission. Communication from the Commission to the European Parliament, the European Council, the Council and the European Investment Bank on establishing a new Partnership Framework with third countries under the European Agenda on Migration. COM (2016) 385 Final (7.6.2016).

55 Joint Way Forward on migration issues between Afghanistan and the EU (2.10.2016).

56 Matuşescu, Constanta. "Considerations on the Legal Nature and Validity of the EU-Turkey Refugee Deal.” Union of Jurists of Romania Law Review (2016):100. 


\section{Sonuç}

Ege'de göçmen ölümlerini azaltmayı hedefleyen 18 Mutabakatı, caydırıcı etkisiyle bunu büyük ölçüde başarmıştır. Mutabakatın temel unsuru olan "1'e 1" uygulamasının uluslararası hukuka ve AB hukukuna aykırı olduğu iddia edildiğinden, $\mathrm{AB}$ kurumları ABAD'ın yargı denetimine takılmasını engellemek için mutabakatla ilgileri olmadığını iddia etmişlerdir. Siyaseten mantıklı bir tercih olarak görünmekle beraber, $\mathrm{AB}$ açısından hukuken oldukça sorunlu bir durum ortaya çıkmıştır.

18 Mart Mutabakatı ve akdedildiği bağlam hukuken ve fiilen irdelendiğinde, bu metnin $\mathrm{AB}$ adına hareket eden $\mathrm{AB}$ Zirvesi ile Türkiye arasında yapılan bir politik mutabakat olduğu anlaşılmaktadır. ABAD ise mutabakatın uluslararası anlaşma niteliğine sahip olup olmadığ ile ilgilenmemiş, $\mathrm{AB}$ kurumlarının sorumluluktan sırılmayı amaçlayan argümanlarını temel alarak, $\mathrm{AB}$ üyesi ülkelerin Devlet ve Hükümet Başkanlarının Türkiye ile akdettiği bir metin olarak kabul ederek, yargı denetimi görevini ifa etmemeyi tercih etmiştir.18 Mart Mutabakatının siyasi bir manevrayla hukuken $\mathrm{AB}$ tarafından öksüz bırakılmış olması, bütünleşmesinin temeli hukuk olan bir Birlik için ciddi bir sorundur.

ABAD'ın 18 Mart Mutabakatına ilişkin kararı Türkiye'de fazla ses getirmediyse de, Türkiye-AB ilişkileri açısından ciddi sonuçları olduğu açıktır. Bir kere, karşılıklı güven sorununu iyice derinleştirecek bir karar olarak belirmektedir. Zira, Türk kamuoyunun ve Türk yetkililerinin Mutabakatın AB ile yapıldığına dair bir şüphesi bulunmamaktadır. Oysa, AB kurumlarının aldığı bu pozisyon, Türkiye ile $\mathrm{AB}$ arasında özellikle son dönemde güçlenen güven bunalımını derinleştirecek niteliktedir. Buna ilaveten, gelecekte yapılacak Türkiye-AB zirvelerinde alınacak kararların da hukukiliği tartışmaya açılacağından, ileride benzer anlaşmaların yapılması olasılığı azalacaktır. AB'nin 18 Mart Mutabakatını sahipsiz bırakması, bundan sonra düzenlenecek Türkiye-AB Zirvelerinin de AB kurumları ile mi yoksa üye ülke Devlet ve Hükümet Başkanları ile mi yapıldığı sorusunu gündeme getirecek ve bu zirvelerin ve zirvelerde alınacak kararların sorgulanmasına neden olacaktır. 
Türkiye-AB ilişkilerinin temel olarak iki hukuki boyutu bulunmaktadır: 1963 Ankara Anlaşmass ${ }^{57}$ temelinde yükselen ortaklık ilişkisi ve 1987 yılında tam üyelik başvuru ile başlayan ve 1999 yılında resmileşen adaylık süreci. Ancak, özellikle son dönemde, Türkiye-AB ilişkilerinde yaşanan siyasi gerginlikler nedeniyle her iki boyutta da tıkanmalar olduğu bir vakıadır. Müzakere sürecinde Kıbrıs sorunu ileri sürülerek AB Konseyi'nin kararıyla siyasi reformlar açısından önem arz eden 23. Fasıl ve 24. Fasıl da dâhil olmak üzere 8 fasıl yıllardır bloke edilmektedir. Öte yandan, Gümrük Birliği’ndeki mevcut sorunların giderilmesi amaciyla öngörülen güncelleme süreci de özellikle 15 Temmuz 2016 darbe girişimi sonrasında gerilen ilişkiler nedeniyle gerçekleşememiştir. Reelpolitik çerçevede Türkiye ile ilişkileri devam ettirmeye ihtiyacı olan $\mathrm{AB}$ de hukuki anlamda yaratıcı ama şüpheli yöntemlerle, ilişkinin hukuki boyutlarında ilerlemek yerine başka mecralarda ilerleyerek bu tıkanıklıkları aşmaya çalışmaktadır. Sözgelimi, 2012 yılında özellikle 23. Fasıl ve 24. Fasılda görüşmeleri sürdürebilmek amacıyla $\mathrm{AB}$ mevzuatında yer almayan "Pozitif Gündem" adında bir süreç yürütülmüştü. $\mathrm{AB}$ hukuku bakımından hiçbir geçerliliği olmayan bu süreç, politik bir düzenleme olarak hayata geçirilmiş, bir nevi günü kurtarmak amaçlanmıştı. AB'nin benzer yaratıcılı̆̆ını, 18 Mart Mutabakatında da ortaya koyduğunu söylemek yanlış olmayacaktır. Göç, mülteci ve vize başlığını içeren 24. Fasıl altında katılım müzakereleri çerçevesinde gerçekleştirilmesi gereken düzenlemeler, Fasıl bloke olduğundan, 18 Mart Mutabakatı gibi gri bölgedeki bir enstrümanla çözümlenmeye çalışılmıştır. Nitekim 18 Mart Mutabakatında öngörülen uygulamanın "geçici ve olağanüstü bir tedbir" olacağı ifade edilmektedir. Oysa kalıcı sorunlara geçici ve olağanüstü tedbirler değil, kalıcı ve sistematik tedbirler getirilmelidir. $\mathrm{Bu}$ da ancak katılım sürecinde ilgili faslına altındaki müzakerelerde ilerleme sağlanmasıyla olabilir. AB'nin ikili ilişkilerdeki güncel ve acil sorunları, Türkiye-AB ilişkilerinin iki temel boyutunda çözümlemek yerine bu iki boyut dışına çıkararak, gri alanlarda çözümlemeye çalışması ne yazık ki Türkiye'yi aday/ortak ülke yerine üçüncü ülke olarak konumlandırmasının bir sonucu olarak değerlendirilebilir.

AB'nin bu politikasını basit bir şekilde çifte standartlarla açıklamak doğru olmayacaktır. Zira burada bir strateji söz konusudur. AB'nin Türkiye

57 Official Journal of the European Communities, Agreement establishing an Association between the European Communities and Turkey, No.L361/29, (31.12.77). 
ile ilişkilerde özellikle son dönemlerde, ABD'nin efsanevi Dışişleri Bakanı Henry Kissinger'la özdeşlemiş "yapıcı belirsizlik" (constructive ambiguity) politikasına başvurduğu söylenebilir. ${ }^{58}$ Gerçekten de AB'nin Türkiye ile ilişkilerde, diplomasinin hassas alanlarında belli siyasi hedeflere ulaşmak üzere kasten belirsiz alanların, ifadelerin, enstrümanların kullanılması yöntemine karşılık gelen "yapıcı belirsizlik" politikası güttüğü açıktır. Nihayetinde AB bunu çıkarları doğrultusunda bazı politikaları devam ettirebilmek amacıyla bir gri alan yaratarak bir taraftan çıkarları doğrultusunda politikaların dilediği şekilde yürütülmesini sağlamakta ve sağlamaya çalışmakta, diğer taraftan da katılım sürecinde Türkiye'yi oyalayarak istediği format ve hızda ilişkileri devam ettirmektedir. Böyle bir yaklaşım hiç şüphesiz normatif bir güç olma iddiasındaki AB'nin kredibilitesine ciddi bir darbe indirmektedir. AB'nin kredibilitesinin hangi noktaya geldiğini görmek açısından Türk kamuoyu nezdindeki inandırıcılığına bakmak yeterli olacaktır.

58 Berridge, G.R. and Alan James. 2003. Constructive Ambiguity. A Dictionary of Diplomacy. 2nd ed. Basingstoke: Palgrave MacMillan. 


\section{Kaynakça}

Arribas, Gloria. "The EU-Turkey Statement, The Treaty-Making Process and Competent Organs, Is the Statement an International Agreement?"European Papers Vol.2 (2017): 303-309.doi: 10.15166/2499-8249/131

Avrupa Birliği Genel Sekreterliği. Avrupa Birliği Antlaşmast ve Avrupa Birliği’nin İşleyişi Hakkında Antlaşma (2011).

Bayraktaroğlu Özçelik, Gülüm. “Avrupa Topluluğunun Milletlerarası Özel Hukuk Alanında Uluslararası Anlaşma Akdetme Yetkisi ve C-01/03 Sayılı VE 7 Şubat 2006 Tarihli Avrupa Toplulukları Adalet Divanı Görüşü.” Ankara Üniversitesi Hukuk Fakültesi Dergisi 57:2 (2008): 17-49.

Berridge, G.R. ve Alan James. Constructive Ambiguity: A Dictionary of Diplomacy 2. Bask1 (Basingstoke: Palgrave MacMillan, 2003).

Cannizzaro, Enzo. "Denialism as the Supreme Expression of Realism: A Quick Comment on NF v. European Council." European Papers Vol.2 (2017): 251 257. doi: 10.15166/2499-8249/120.

Carrera, Sergio, Leonhard den Hertog ve Marco Stefan."It wasn't me!: The Luxembourg Court Orders on the EU-Turkey Refugee Deal." CEPS Policy Insights (Nisan 2017).

Case T-192/16 - NF v European Council (28 February 2017). Erişim Tarihi: Haziran 2021. https://curia.europa.eu/juris/document/document.jsf;jsessionid=C1D930328036 067FFEEBFE0AABDCE054?text $=\&$ docid $=188483 \&$ pageIndex $=0 \&$ doclang $=\mathrm{e}$ $\mathrm{n} \&$ mode $=$ lst \&dir $=\&$ occ $=$ first $\&$ part $=1 \& \mathrm{cid}=15382687$

Case C-45/07, Commission v. Greece (12 February 2009).Erişim Tarihi: Haziran 2021. https://curia.europa.eu/juris/document/document.jsf?text=\&docid=78181\&pag eIndex $=0 \&$ doclang $=$ en $\&$ mode $=1$ st $\&$ dir $=\&$ occ $=$ first $\&$ part $=1 \&$ cid $=15616389$

Case C-22/70, Commission v. Council, (31 March 1971). Erişim Tarihi: Haziran 2021. https://curia.europa.eu/juris/showPdf.jsf;jsessionid=5E0C3F346A72EE840E53 96FFD1 A5CAFF?text $=\&$ docid $=88062 \&$ pageIndex $=0 \&$ doclang $=$ en $\&$ mode $=1$ st $\& \operatorname{dir}=\& o c c=$ first $\&$ part $=1 \&$ cid $=7794642$

Council Decision (EU) 2016/1754 of 29 September 2016 amending Decision (EU) $2015 / 1601$ establishing provisional measures in the area of international protection for the benefit of Italy and Greece, OJ L 268/82 (1.10.2016). Erişim Tarihi: Haziran 2021. https://eur-lex.europa.eu/legal-content/EN/TXT/PDF/ ?uri=CELEX:32016D1754\&from=EN

Den Heijer, Maarten ve Thomas Spijkerboer. "Is the EU-Turkey Refugee and Migration Deal a Treaty." EU Law Analysis (Nisan 2016). Erişim Tarihi: Haziran 2021. http://eulawanalysis.blogspot.com/2016/04/is-eu-turkeyrefugee-and-migration-deal.html 
Ekşi, Nuray. "18 Mart 2016 Tarihli AB-Türkiye Zirvesi Bildirisinin Hukuki Niteliği."Contemporary Research in Economics and Social Sciences 1 (2017): 47-85.

European Commission.EU-Turkey Statement One Year On(2017). Erişim Tarihi: Haziran 2021. https://ec.europa.eu/home-affairs/sites/default/files/what-wedo/policies/european-agenda-migration/background-information/eu_turkey_ statement_17032017_en.pdf

European Commission. Communication from the Commission to the European Parliament, the European Council, the Council and the European Investment Bank on establishing a new Partnership Framework with third countries under the European Agenda on Migration, COM (2016) 385 Final (7.6.2016). Erişim Tarihi: Haziran 2021. https://ec.europa.eu/home-affairs/sites/default/files/whatwe-do/policies/european-agenda-migration/proposal-implementation-package/ docs/20160607/communication_external_aspects_eam_towards_new_migratio n_ompact_en.pdf

European Commission. Communication from the Commission to the European Parliament, the European Council and the Council:Next Operational Steps in EU-Turkey Cooperation in the Field of Migration, $\operatorname{COM(2016)166~Final~}$ (16.3.2016). Erişim Tarihi: Haziran 2021.

European Commission. Communication from the Commission to the European Parliament and the Council on the State of Play of Implementation of Priority Actions under the European Agenda on Migration $\operatorname{COM(2016)~} 85$ Final (10.2.2016). Erişim Tarihi: Haziran 2021. https://ec.europa.eu/homeaffairs/sites/default/files/what-we-do/policies/european-agenda-migration/ proposal-implementation-package/docs/managing_the_refugee_crisis_state_ of_play_20160210_en.pdf

European Council. EU-Turkey Statement (18 March 2016). Erişim tarihi: Haziran 2021. https://www.consilium.europa.eu/en/press/press-releases/2016/03/18/euturkey-statement/

Gatti, Mauro. "The EU-Turkey Statement: A Treaty that Violates Democracy." Blog of the European Journal of International Law. 18 April 2016. Erişim Tarihi: Haziran 2021. https://www.ejiltalk.org/the-eu-turkey-statement-a-treaty-thatviolates-democracy-part-1-of-2/

Goldner Lang, Iris.“Towards 'Judicial Passivism' in EU Migration and Asylum Law?" (Mayıs 9, 2020). Erişim Tarihi: Haziran 2021. https://ssrn.com/abstract=3597017

Idriz, Narin. "The EU-Turkey Deal in front of the Court of Justice of the EU: An Unsolicited Amicus Brief." Asser Policy Brief No.3 (2017).

International Court of Justice, Case Concerning Maritime Delimitation and Territorial Questions Between Qatar and Bahrain (Judgement of 1 July 1994) Erişim Tarihi: Haziran 2021. https://www.icj-cij.org/public/files/caserelated/87/087-19940701-JUD-01-00-EN.pdf 
International Court of Justice, Reports of Judgments, Advisory Opinions and Ordes Aegean Sea Continental Shelf Case (Greece v. Turkey) (Judgement of 19 December 1978) Erişim Tarihi: Haziran 2021.https://www.icjcij.org/public/files/case-related/62/062-19781219-JUD-01-00-EN.pdf

Joined Cases C-208/17 P to C-210/17 P, NF v European Council (12 Eylül 2018). Erişim Tarihi: Haziran 2021 https://curia.europa.eu/juris/document/ document.jsf?text $=\&$ docid $=205744 \&$ pageIndex $=0 \&$ doclang $=$ en $\&$ mode $=1$ st $\&$ di $\mathrm{r}=\&$ occ $=$ first\&part $=1 \& \mathrm{cid}=15384406$

Joined Cases C-181/91 and C-248/91, European Parliament v Council of the European Communities and Commission of the European Communities (30 Haziran 1993). Erişim Tarihi: Haziran 2021. https://eur-lex.europa.eu/ resource.html?uri=cellar:9e85e532-52d8-4ce6-987fbfccb829c6d7.0002.03/DOC_1\&format=PDF

Joint Way Forward on migration issues between Afghanistan and the EU (2 October 2016) Erişim Tarihi: Haziran 2021. https://eeas.europa.eu/sites/default/files/ eu_afghanistan_joint_way_forward_on_migration_issues.pdf

Karaca, Hüseyin Akif. "Türkiye-Avrupa Birliği Geri Kabul Antlaşması ve 18 Mart 2016 Tarihli Türkiye-Avrupa Birliği Zirve Bildirisi Uyarınca Düzensiz Göçle Mücadele ve Bazı Sorunlu Alanlar." Ankara Hacı Bayram Veli Üniversitesi Hukuk Fakültesi Dergisi 24 (2020): 155-194.

Kaya, Hülya, The EU-Turkey Statement on Refugees: Assessing its Impact on Fundamental Rights. Cheltenham: Edward Elgar (2020).

Lehner, Roman. "The EU-Turkey 'deal': Legal Challenges and Pitfalls." International Migration Vol.57(2) (2019): 176-185.

Matuşescu, Constanta. "Considerations on the Legal Nature and Validity of the EUTurkey Refugee Deal." Union of Jurists of Romania Law Review (Aral1k 2016): 91-101.

Official Journal of the European Union, Commission Decision of 24 November 2015 on the coordination of the actions of the Union and of the Member States through a coordination mechanism - the Refugee Facility for Turkey(8.12.2015). Erişim Tarihi: Haziran 2021. https://eur-lex.europa.eu/ legal-content/EN/TXT/PDF/?uri=CELEX:32015D1208(02)\&from=EN

Öztürk, Neva Övünç ve Cavidan Soykan. "Third Anniversary of EU-Turkey Statement: A Legal Analysis.” Heinrich Böll Stiftung (Aralık 2019). Erişim Tarihi: Haziran 2021, https://tr.boell.org/en/2019/10/03/third-anniversary-euturkey-statement-legal-analysis

Pazarc1, Hüseyin. Uluslararası Hukuk. 6. Bask1. Turhan Kitabevi (2008).

Vienna Convention on the Law of Treaties (1969) Erişim Tarihi: Haziran 2021. https://legal.un.org/ilc/texts/instruments/english/conventions/1_1_1969.pdf 